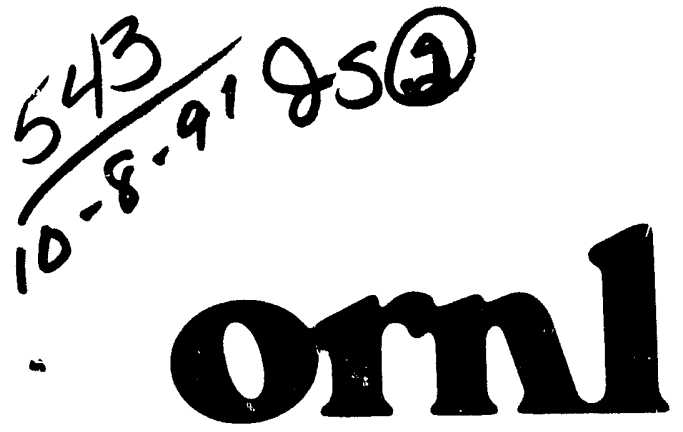

OAK RIDGE NATIONAL LABORATORY

MARTIN MARUETTA
ORNL-6485
DOE Assay Methods Used for Characterization of Contact-Handled Transuranic Waste

\author{
F. J. Schultz \\ J. T. Caldwell
}


This report has been reproduced directly from the best available copy.

Available to DOE and DOE contractors from the Office of Scientific and Technical Information, P.O. Box 62, Oak Ridge, TN 37831; prices available from (615) 576-8401, FTS 626-8401.

Available to the public from the National Technical Information Service, U.S. Department of Commerce, 5285 Port Royal Rd., Springfield, VA 22161.

This report was prepared as an account of work sponsored by an agency of the United States Government. Neither the United States Government nor any agency thereof, nor any of their employees, makes any warranty, express or implied, or assumes any legal liability or responsibility for the accuracy, com pleteness, or usefulness of any information, apparatus, product, or process disclosed, or represents that its use would not infringe privately owned rights. Reference herein to any specific commercial product, process, or service by trade name, trademark, manufacturer, or otherwise, does not necessarily constitute or imply its endorsement, recommendation, or favoring by the United States Government or any agency thereof. The views and opinions of authors expressed herein do not necessarily state or reflect those of the United States Government or any agency thereof. 


\title{
DOE ASSAY METHODS USED FOR CHARACTERIZATION OF CONTACT-HANDLED TRANSURANIC WASTE
}

\author{
F. J. Schultz
}

Oak Ridge National Laboratory

J. T. Caldwell

Pajarito Scientific Corporation

Date Published: August 1991

Prepared for the

Office of Defense Programs

No. EW 301001

\author{
Prepared by \\ OAK RIDGE NATIONAL LABORATORY \\ Oak Ridge, Tennessee 37831 \\ managed by \\ MARTIN MARIETTA ENERGY SYSTEMS, INC. \\ for the \\ U.S. DEPARTMENT OF ENERGY \\ Under Contract No. DE-AC05-84OR21400
}




\section{CONTENTS}

LIST OF FIGURES $\ldots \ldots \ldots \ldots \ldots \ldots \ldots \ldots \ldots \ldots \ldots \ldots \ldots \ldots$

LIST OF TABLES $\ldots \ldots \ldots \ldots \ldots \ldots \ldots \ldots \ldots \ldots \ldots \ldots \ldots \ldots \ldots \ldots \ldots$

ACRONYMS AND INITIALISMS $\ldots \ldots \ldots \ldots \ldots \ldots \ldots \ldots \ldots \ldots \ldots \ldots \ldots$

ACKNOWLEDGMENTS $\ldots \ldots \ldots \ldots \ldots \ldots \ldots \ldots \ldots \ldots \ldots \ldots \ldots \ldots \ldots \ldots$

ABSTRACT $\ldots \ldots \ldots \ldots \ldots \ldots \ldots \ldots \ldots \ldots \ldots \ldots \ldots \ldots \ldots \ldots \ldots \ldots \ldots \ldots$

1. INTRODUCTION $\ldots \ldots \ldots \ldots \ldots \ldots \ldots \ldots \ldots \ldots \ldots \ldots \ldots \ldots \ldots$

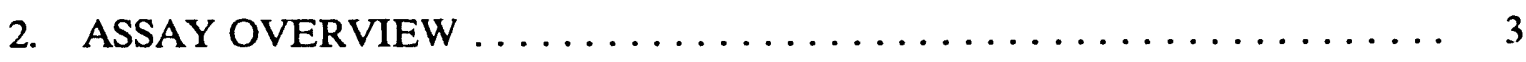

3. ASSAY METHODS, CHARACTERISTICS, AND LIMITATIONS . . . . . 6

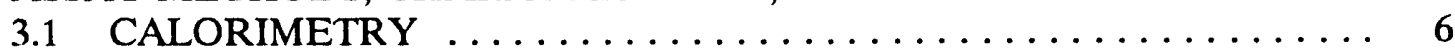

3.2 PASSIVE GAMMA ASSAYS $\ldots \ldots \ldots \ldots \ldots \ldots \ldots \ldots \ldots \ldots \ldots$

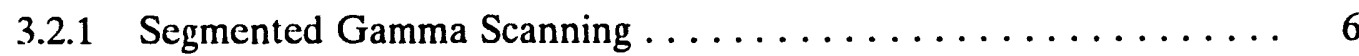

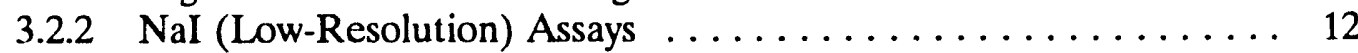

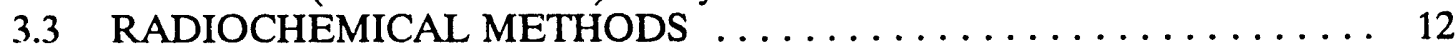

3.4 PASSIVE NEUTRON COINCIDENCE COUNTING ASSAYS . . . . . 13

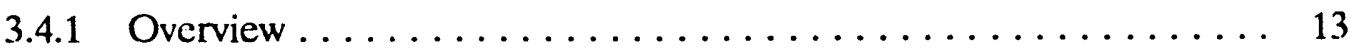

3.4.2 Applicability to Contact-Handled

Transuranic Wastes .................... 14

3.4.3 Instrument Calibration, Standards

Preparation, and Implementation .............. 14

3.4.4 Operator Training Requirements and

Practices ......................... 14

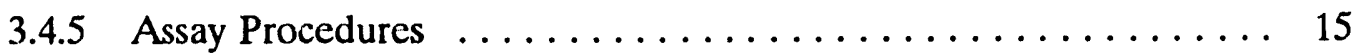

3.4.6 Assay Precision, Bias, and Limit of

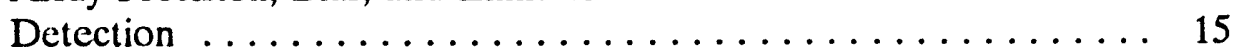

3.5 PASSIVE-ACTIVE NEUTRON ASSAY SYSTEM . . . . . . . . 17

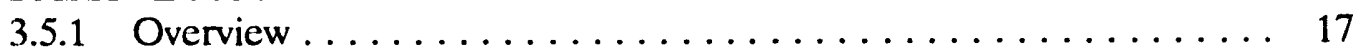

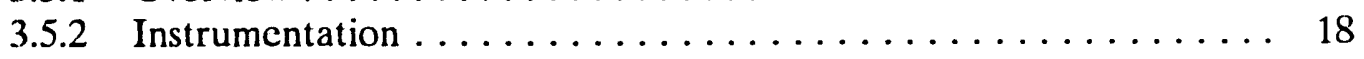

3.5.3 Passive-Active Neutron Assay Matrix

Corrections ......................... 19

3.5.4 Assay Algorithm and Data Acquisition

System ........................ 24

3.5.5 Applicability to Contact-Handled

Transuranic Wastes ...................... 26

3.5.6 Instrument Calibration, Standards

Preparation, and Implementation . . . . . . . . . . . 26

3.5.7 Operator Training Requirements and

Practices ........................... 26

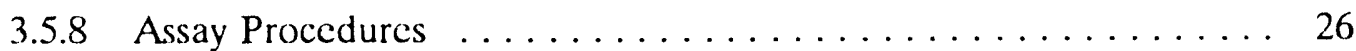


3.5.9 Assay Precision, Bias, and Limit of Detection ........................ 28

3.5.10 Passive-Active Neutron Assay Results

Comparisons ........................ 29

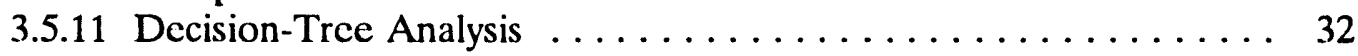

4. FISSILE MATERIAL CONTENT AND DECAY HEAT VALUE

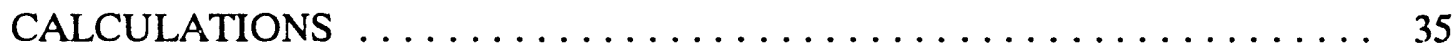

5. NEW NONDESTRUCTIVE ASSAY DEVELOPMENTS $\ldots \ldots \ldots \ldots \ldots \ldots 37$

6. QUALITY ASSURANCE AND QUALITY CONTROL PRACTICES . . . . 38

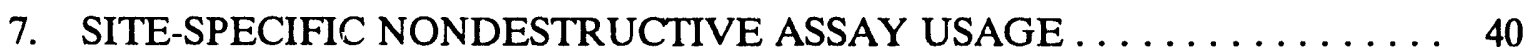

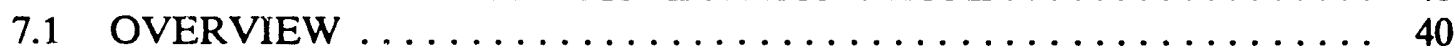

7.2 ARGONNE NATIONAL LABORATORY .............. 40

7.3 IDAHO NATIONAL ENGINEERING LABORATORY $\ldots \ldots \ldots \ldots \ldots .40$

7.4 LAWRENCE LIVERMORE NATIONAL LABORATORY . . . . . . . . 41

7.5 LOS ALAMOS NATIONAL LABORATORY $\ldots \ldots \ldots \ldots \ldots \ldots \ldots .41$

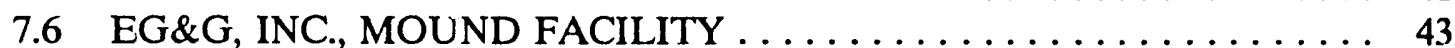

7.7 NEVADA TEST SITE $\ldots \ldots \ldots \ldots \ldots \ldots \ldots \ldots \ldots \ldots \ldots \ldots \ldots \ldots \ldots$

7.8 CAK RIDGE NATIONAL LABORATORY $\ldots \ldots \ldots \ldots \ldots \ldots \ldots \ldots$.

7.9 WESTINGHOUSE HANFORD $\ldots \ldots \ldots \ldots \ldots \ldots \ldots \ldots \ldots \ldots \ldots$

7.10 SAVANNAH RIVER SITE $\ldots \ldots \ldots \ldots \ldots \ldots \ldots \ldots \ldots \ldots \ldots$

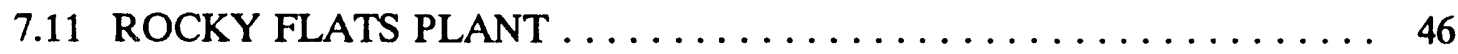

8. CONCLUSIONS $\ldots \ldots \ldots \ldots \ldots \ldots \ldots \ldots \ldots \ldots \ldots \ldots \ldots \ldots \ldots$

9. REFERENCES .......................... 49 


\section{LIST OF FIGURES}

Figure

Page

1 Schematic arrangement for the segmented

gamma-ray scanning system

Basic cross-sectional view of a typical Los Alamos

National Laboratory passive-active neutron detection

system showing the schematic "interwoven" layout of the

two distinct types of neutron detection packages $\ldots \ldots \ldots \ldots \ldots$

Moderator index measured for the passive-active neutron

system using the detector ratio method $\ldots \ldots \ldots \ldots \ldots \ldots \ldots$

Use of the moderator index to determine passive neutron coincidence matrix correction factors for a passive-active neutron system $\ldots \ldots \ldots \ldots \ldots \ldots \ldots \ldots \ldots \ldots \ldots \ldots \ldots \ldots \ldots \ldots$

Passive-active neutron system active assay matrix correction factors measured at Hanford, Idaho National Engineering Laboratory, and the Savannah River Plant with a set of 20 standard matrix drums

Comparison of $\mathbf{3 0 0}$ Hanford contact-handled transuranic waste drum assays performed with the passive-active neutron system (passive neutron compared with active neutron)

7 Comparison assay data sets of 200 Lawrence Livermore National Laboratory contact-handled transuranic waste drums; waste matrix is nonsegregated general laboratory waste: $(a)$ passive neutron (PAN) compared with segmented gamma scanning (SGS), (b) active neutron (PAN) compared with SGS, and (c) comparison of the two independent PAN passive neutron assay systems .......

Assay comparisons of a set of over 200 Rocky Flats Plant (RFP) contact-handled transuranic waste drums (graphite molds matrix) showing RFP segmented gamma scanning system assays compared with (a) PAN unit passive neutron assays and (b) Idaho National Engineering Laboratory PAN active neutron and passive neutron comparisons

9 Batch average plutonium assays of 1300 sludge drums performed at the Rocky Flats Plant compared with passive-active neutron assays of the same drums performed at Idaho National Engineering

Laboratory . . . . . . . . . . . . . . . . . . . . . . . . . . . 
10 Idaho National Engineering Laboratory standards measurements (Pink Drum) performed over a 3 -year period: $(a)$ passive standard

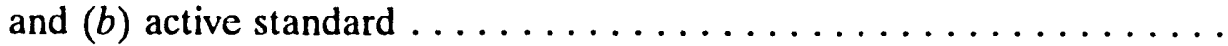




\section{LIST OF TABLES}

Table

Page

1 Summary of assay methods used at DOE contractor sites for characterization of contact-handled transuranic waste .......... 1

2 Segmented gamma scanner assay precisions for low-density wastes contained in a $208-\mathrm{L}$ drum $\ldots \ldots \ldots \ldots \ldots \ldots \ldots \ldots$

Segmented gamma scanner assay biases

4

Summary of passive assay coincidence counting assay error contributions

Passive assay coincidence counting assay biases 


\section{ACRONYMS AND INITIALISMS}

$\begin{array}{ll}\text { AI } & \text { absorber index } \\ \text { ANL-E } & \text { Argonne National Laboratory-East } \\ \text { ANSI } & \text { American National Standards Institute } \\ \text { ASTM } & \text { American Society for Testing and Materials } \\ \text { CALIBP } & \text { calibration } \\ \text { CH-TRU } & \text { contact-handled transuranic (waste) } \\ \text { CRT } & \text { cathode ray tube } \\ \text { DOE } & \text { Department of Energy } \\ \text { ETWAF } & \text { Experimental Transuranic Waste Assay Facility } \\ \text { Hanford } & \text { Westinghouse Hanford Corporation } \\ \text { HSG } & \text { heat source grade } \\ \text { IBM/PC } & \text { International Business Machines personal computer } \\ \text { INEL } & \text { Idaho Nuclear Engineering Laboratory } \\ \text { ISOP } & \text { isotopics } \\ \text { LANL } & \text { Los Alamos National Laboratory } \\ \text { LLNL } & \text { Lawrence Livermore National Laboratory } \\ \text { LLW } & \text { low-level waste } \\ \text { MCFA } & \text { matrix correction factor-active assay } \\ \text { MCFP } & \text { matrix correction factor-passive assay } \\ \text { MEGAS } & \text { Multienergy Gamma Assay System } \\ \text { MI } & \text { moderator index } \\ \text { Mound } & \text { EG\&G Inc., Mound Facility } \\ \text { NDA } & \text { nondestructive assay } \\ \text { NDE } & \text { nondestructive examination } \\ \text { NRC } & \text { Nuclear Regulatory Commission } \\ \text { NTX } & \text { Nevada Test Site } \\ \text { ORNL } & \text { Oak Ridge National Laboratory } \\ \text { PAN } & \text { passive-active neutron (assay) } \\ \text { PNCC } & \text { passive neutron coincidence counting } \\ \text { QA } & \text { quality assurance } \\ \text { QC } & \text { quality control } \\ \text { R\&D } & \text { research and development } \\ \text { RFP } & \text { Rocky Flats Plant } \\ \text { RG } & \text { reactor grade } \\ \text { ROI } & \text { region of interest } \\ \text { RTR } & \text { real-time radiography } \\ \text { SGS } & \text { segmented gamma scan } \\ \text { SWEPP } & \text { Solid Waste Examination Pilot Plant } \\ \text { SYSDT } & \text { system dead time } \\ \text { SYSMULT } & \text { system multiplication } \\ \text { WG } & \text { weapons grade } \\ \text { WIPP } & \text { Waste Isolation Pilot Plant } \\ & \end{array}$




\section{ACKNOWLEDGMENTS}

The authors express their appreciation to members of the Nondestructive Assay/Nondestructive Examination Interface Working Group for their review of the draft, to Ron A. Harlan and J. Gilmer (Rocky Flats Plant) for their meticulous review of the revised manuscript, and to J. Richard Smith (Idaho National Engineering Laboratory, Idaho Falls) for allowing a portion of his unpublished work to be included. 


\begin{abstract}
U.S. Department of Energy methods used for characterization of contact-handled transuranic (CH-TRU) waste prior to shipmeni to the Waste Isolation Pilot Plant (WIPP) are described and listed by contractor site. The methods described are part of the certification process. All CH-TRU waste must be assayed for determination of fissile material content and decay heat values prior to shipment and prior to storage on-site. Both nondestructive assay (NDA) and destructive assay methods are discussed, and new NDA developments such as passive-active neutron (PAN) crate counter improvements and neutron imaging are detailed. Specifically addressed are assay method physics; applicability to CH-TRU wastes; calibration standards and implementation; operator training requirements and practices; assay procedures; assay precision, bias, and limit of detection; and assay limitation.

While PAN is a new technique and does not yet have established American Society for Testing and Materials, American National Standards Institute, or Nuclear Regulatory Commission guidelines or methods describing proper calibration procedures, equipment setup, etc., comparisons of PAN data with the more established assay methods (e.g., segmented gamma scanning) have demonstrated its reliability and accuracy. Assay methods employed by DOE have been shown to be reliable and accurate in determining fissile, radionuclide, alpha-curie content, and decay heat values of $\mathrm{CH}$-TRU wastes. These parameters are therefore used to characterize packaged waste for use in certification programs such as that used in the shipment of CH-TRU waste to the WIPP.
\end{abstract}




\section{INTRODUCTION}

Contact-handled transuranic (CH-TRU) waste must be assayed for determination of fissile material content and decay heat values prior to shipment. U.S. Department of Energy (DOE) contractor sites that generate and/or store one or more types of CH-TRU waste (e.g., sludge, general laboratory waste, etc.) are:

1. Argonne National Laboratory-East (ANL-E),

2. Idaho National Engineering Laboratory (INEL),

3. Lawrence Livermore National Laboratory (LLNL),

4. Los Alamos National Laboratory (LANL),

5. EG\&G Inc., Mound Facility (Mound),

6. Nevada Test Site (NTS),

7. Oak Ridge National Laboratory (ORNL),

8. Westinghouse Hanford Corporation (Hanford),

9. Rocky Flats Plant (RFP), and

10. Savannah River Site (SRS).

Assay methods used at these DOE contractor sites are (1) passive gamma [i.e., Ge, $\mathrm{Ge}(\mathrm{Li})$, and $\mathrm{NaI}$-transmission-corrected and noncorrected], (2) radiochemical assay-gross alpha and gamma spectrometry, (3) passive neutron coincidence counting (PNCC), (4) passive-active neutron assay (PAN), and (5) calorimetry. Table 1 lists these methods by site.

Table 1. Summary of assay methods used at DOE contractor sites for characterization of contact-handled transuranic waste

\begin{tabular}{lcccccc}
\hline \multicolumn{1}{c}{ Site } & $\begin{array}{c}\text { SGS or } \\
\mathrm{Nal}^{b}\end{array}$ & PNCC $^{c}$ & $\begin{array}{c}\text { PAN } \\
\text { (drum) }\end{array}$ & $\begin{array}{c}\text { PAN } \\
\text { (box) }\end{array}$ & Radiochemistry & $\begin{array}{c}\text { Mobile } \\
\text { PAN }\end{array}$ \\
\hline $\begin{array}{c}\text { Argonne National } \\
\text { Laboratory-East }\end{array}$ & $\mathrm{X}$ & & & $\mathrm{X}$ & & \\
$\begin{array}{l}\text { Westinghouse } \\
\text { Hanford Corporation }\end{array}$ & $\mathrm{X}$ & & $\mathrm{X}$ & & & \\
$\begin{array}{l}\text { Idaho National } \\
\text { Engineering Laboratory }\end{array}$ & & & $\mathrm{X}$ & $\mathrm{X}$ & & \\
$\begin{array}{l}\text { Los Alamos National } \\
\text { Laboratory }\end{array}$ & $\mathrm{X}$ & $\mathrm{X}$ & $\mathrm{X}$ & & $\mathrm{X}$ & $\mathrm{X}$ \\
$\begin{array}{l}\text { Lawrence Livermore } \\
\text { National Laboratory }\end{array}$ & $\mathrm{X}$ & & & & $\mathrm{X}$ & $\mathrm{X}$ \\
$\begin{array}{c}\text { EG\&G Inc., Mound } \\
\text { Facility }\end{array}$ & $\mathrm{X}$ & & & & $\mathrm{X}$ & \\
$\begin{array}{l}\text { Nevada Test Site } \\
\text { Oak Ridge National }\end{array}$ & $\mathrm{X}$ & & $\mathrm{X}$ & & & $\mathrm{X}$ \\
$\quad$ Laboratory & $\mathrm{X}$ & $\mathrm{X}$ & $\mathrm{X}$ & $\mathrm{X}$ & $\mathrm{X}$ & \\
$\begin{array}{l}\text { Rocky Flats Plant } \\
\text { Savannah River Site }\end{array}$ & $\mathrm{X}$ & $\mathrm{X}$ & $\mathrm{X}$ & & & \\
\hline
\end{tabular}

The calorimetry method is also used to obtain quantitative radionuclide content.

bSGS-segmented gamma scan, $\mathrm{NaI}$-sodium-iodine.

'PNCC-passive neutron coincidence counting.

PAN-passive-active neutron assay. 
DCE and its site contractors have historically been, and continue to be, the dominant force in assay technology development and implementation-not only within the United States but internationally as well. Some of the assay technologies (i.e., passive gamma, radiochemistry, and $\mathrm{PNCC}$ ) are highly developed and have a long history of implementation-first, to nuclear products (i.e., safeguards and material accounting), and eventually, to nuclear scraps and wastes. Other assay technoiogies such as PAN are newer developments (i.e., circa 1980) and were devised especially for application to bulk TRU waste assays under sponsorship of DOE. Additional improvements to the assay technology continue to be made and implemented as indicated in this document.

Where practical, DOE site contractors perform multiple assays of waste packages as well as real-time radiography (RTR) inspection. The multiple assay measurements gencrally take the form of a passive gamma assay [i.e., usually segmented gamma scanner (SGS)] at the waste generator site followed by PAN assay (i.e., two independent assay measurements) at a central certification facility. This is equivalent to three independent nondestructive assay (NDA) measurements of both fissile content and decay heat performed on each 208-L waste drum. The certification facility also performs RTR measurements on each 208-L waste drum; this includes routine on-line identification and verification of content code as well as archiving (by videotape) of all RTR scans of TRU waste drums.

These practices, as well as quality assurance (QA) audits and administrative controls, provide assurances that correct values of fissile material and decay heat are assigned to each waste drum. In the case of "special-case" drums or of significant differences among independent NDA measurements, personnel at each site review all available data (including the RTR information and assay records) to determine the appropriate action. If a reasonable assay value cannot be ascertained, remedial action is taken: either to reassay if measurement errors are suspected or to repackage if the drum is suspected of nonconformance with respect to fissile material content or decay heat.

Described in the following sections are the NDA and destructive assay methods used in the characterization of $\mathrm{CH}$-TRU waste at DOE sites. DOE assay methods are shown to be reliable and accurate in determining fissile material, radionuclide, alpha-curie content, and decay heat content of CH-TRU wastes. Assay topics specifically addressed include:

1. an overview of the assay method;

2. applicability to $\mathrm{CH}-\mathrm{TRU}$ wastes;

3. calibration standards and implementation;

4. operator training requirements and practices;

5. assay procedurcs,

6. assay precision, uras, and limit of detection; and

7. assay limitations.

The SGS and PAN assay methods (i.e., those primarily used within the DOE complex) are discussed in detail.

All systems or methods except PAN have established American Society for Testing and Materials (ASTM). American National Standards Institute (ANSI), and/or Nuclear Regulatory Commission (NRC) guidelines or methods that describe proper calibration procedures, proper equipment setup, etc. As a new technique, PAN does not yet have a guideline or method developed; however, comparisons of PAN data with the more established assay methods (e.g., SGS or radiochemistry) are given that demonstrate its reiiabiiity and accuracy. $Q \dot{Q}$ and quaiiiy coniroi (QC) praciices used in assay methoús are presented, and new NDA developments such as neutron imaging are discussed. 


\section{ASSAY OVERVIEW}

This section describes the general features of NDA and destructive assay methods used by the DOE site contractors to determine the TRU content of their bulk CH-TRU waste. ANSI defin is NDA as follows:

"The observation of spontaneous or simulated nuclear radiations, interpreted to estimate the content of one or more nuclides of interest in the item assayed, without affecting the physical or chemical form of the material.

active assay. Assay based on the observation of radiation(s) induced by irradiation from an external source.

passive assay. Assay based on the observation of naturally occurring or spontaneous nuclear radiation(s)."

Destructive assay refers to chemical analysis in which a sample aliquot is removed from the item (after ensuring homogenization of the batch) to be assayed and prepared for alpha and/or gamma counting.

The NRC describes the applicable NDA passive measurements: "Radiations attributable to alpha particle decay, to gamma-ray transitions following alpha and beta particle decay, and to spontaneous fission have served as the basis for practical passive

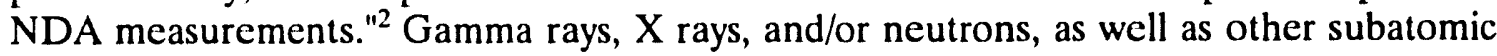
particles, are emitted by the various TRU isotopes as they undergo deexcitation to their respective ground states or more stable energy levels. NDA techniques based on detection of each emitted radiation have been developed and utilized for $\mathrm{CH}$-TRU bulk-waste assay. The passive gamma, PNCC, radiochemical, and calorimetric methods are techniques that are described in the ASTM, ANSI, NRC, and American Society of Mechanical Engineers standards, guidelines, and/or regulations. These documents provide the user with information for proper implementation of these techniques.

Characteristics of any assay measurement include precision, bias, and detection limit. Proper calibration methods must also be employed to reduce or to eliminate the bias of the assay results. Definitions of each of the above terms (obtained from ref. 3 ) follow:

1. Precision is a generic term used to describe the dispersion of a set of measured values.

2. Bias refers to a persistent positive or negative deviation of the method average from the correct value or accepted reference value (also known as "constant" or "systematic error").

3. Detection limit indicates a stated limiting value designating the lowest concentration or mass that can be estimated or determined with confidence and that is specific to the analytical procedure used.

4. Calibration is defined as the determination of the values of the significant parameters by comparison with values indicated by a reference instrument or by a set of reference standards.

Examples for each discussed assay method are found in the appropriate sections. 
Estimates oi precision can be calculated by standard error propagation techniques. ${ }^{4}$ Radioactive decay is random and described by Poisson statistics. For Poisson statistics the variance in measuring $N$ events in a detector is equal to $N$. The standard deviation is the square root of the variance. The variance in a quantity $f$ that is a function of $n$ independent variables $x_{i}$ is given by:

$$
\sigma^{2}(f)=\sum_{i=1}^{n}\left[\frac{\partial f}{\partial_{x_{i}}}\right]^{2} \sigma^{2}\left(x_{i}\right)
$$

The precision of an NDA measurement is not strongly related to the measurement item's adherence to ideal matrix and nuclide density assumptions. For destructive assay methods (e.g., radiochemical) that require sampling, the precision of repeat measurements of a single item will be strongly influenced by a lack of adherence to ideal nuclide density assumptions. However, for SGS systems, measurement bias depends primarily on the adherence of the measurement item to the assumptions of small particle size and homogeneity. Negative assay bias (i.e., reported value less than actual value) will be encountered, for example, when the nuclide is present in lumps that attenuate their own radiation to a greater extent than the surrounding material (i.e., self-absorption).

Radiochemical methods that dissolve material samples will not be affected by lumps. Matrix and nuclide density have no effect on calorimeter measurements. Techniques used to correct for self-absorption effects are used in PNCC and PAN assay techniques. ${ }^{5-7}$ Positive assay bias (i.e., reported value greater than actual value) can sample loadings during PNCC measurements. Typical techniques used to control this interference are (1) equivalent reference standards used for calibration or (2) use of source addition techniques. $^{8}$

Of course, to obtain precise assay measurements, count-rate-dependent losses resulting from phenomena such as pulse pileup and analyzer dead-time characteristics must be monitored and corrected. These corrections are not required for calorimeter measurements. Analyzer dead-time is defined as that period of time (unique to the analyzer) in which it is unable to accept input signals for analysis. This correction is accomplished through the use of a combination of electronic modules and/or radioactive sources and/or computer algorithms (that have been obtained through the assay of calibration standards).

The uncertainty $(W)$ in a measurement is the composite error including both the precision and bias of the measurement. The uncertain in a quantity $f$ that is a function of $n$ independent variable $x_{i}$ is given by:

$$
W=\left[\sum W_{i}^{2}\right]^{1 / 2},
$$


where $W_{i}$ is the uncertainty in the variable $x_{i}$. Assay item preparation is generally limited to good waste/scrap segregation practices that produce the relatively homogencous items that are required for any successful waste/inventory management and assay scheme regardless of the measurement method used. 


\section{ASSAY METHODS, CHARACTERISTICS, AND LIMITATIONS}

This section describes the various assay methods, presents their characteristics (i.e., precision, bias, and detection limits), and discisses their limitations and applicability to assay of $\mathrm{CH}$-TRU wastes. Assay methods discussed include calorimetry, passive gamma assay (e.g., SGS), radiochemical methods, PNCC, and PAN assay.

\subsection{CALORIMETRY}

Calorimetry has been used for many years in the nuclear weapons program for product assay of weapons-grade (WG) plutonium. Many of the NDA plutonium standards in use throughout the DOE complex have been characterized by calorimetry. A large number of standard radiochemical and gravimetric assay comparisons have been performed to verify the accuracy of calorimetric assay measurements.

Basically, calorimeters measure the heat flow out of contained small packages. Because experimental difficulties grow exponentially with package size, this method is generally used only with small packages-a few liters in volume at most. The primary heat release in WG plutonium materials is from alpha and beta decay, and with a knowledge of isotopic composition, precise plutonium mass values are readily obtained from virtually any physical or chemical form of plutonium material without knowledge of precise compound stoichiometry (e.g., plutonium to oxygen ratio).

The kinetic energy of the emitted alpha or beta particle and the energy of the alpha or beta particle and the recoil nucleus are transformed into heat together with some fraction of the gamma ray energies and conversion electrons that may be emitted by the excited daughter nucleus in lowering its energy to a more stable nuclear configuration. The electrons and low-energy gamma rays are totally absorbed, while the higher-energy gamma rays, which may escape from the calorimeter chamber, comprise less than $0.01 \%$ of the total decay energy. Thus most of the energy associated with these transitions of the daughter nucleus to ground state, as well as all of the energy associated with the alpha or beta particle and recoil nucleus, is absorbed within the calorimeter.

The calorimetric method measures the total decay heat produced by an item. The relative isotopic abundances of the plutonium and americium nuclides in the mixture and the values of decay heat per gram for each nuclide are used to calculate the average decay heat per gram of nuclide mixture. The total measured decay heat divided by the average decay heat per gram yields the grams of nuclide mixture. The calorimetry procedure and equipment used for the assay technique is described in ref. 9. This standards method is used in DOE facilities for calorimetry calibrations, setup, and as the guide to operational measurements.

\subsection{PASSIVE GAMMA ASSAYS}

\subsubsection{Segmented Gamma Scanning}

Segmented gamma scanning, as discussed in this subsection, includes high-resolution, transmission-corrected scanning in which hyperpure germanium (HPGe) or lithium-drifted germanium $[\mathrm{Ge}(\mathrm{Li})]$ detectors are used. 


\subsubsection{Overvicw}

The first NDA measurements of TRU isotopes using passive gamma rays were performed by DOE contractor personnel more than 40 years ago. Passive gamma-ray NDA of TRU isotopes is a highly developed technology and is also the most widely implemented. The introduction more than 20 years ago of germanium solid state detectors and the subsequent incorporation of these detectors into computer-based detection packages have improved the resolution and reliability of these systems.

The number of individual TRU isotopes or their daughters that can be assayed with SGS is large: ${ }^{233} \mathrm{U},{ }^{238} \mathrm{Pu},{ }^{239} \mathrm{Pu},{ }^{237} \mathrm{~Np},{ }^{241} \mathrm{Am}$, and ${ }^{243} \mathrm{Am}$ are the more common ones. In each case, one or more characteristic moderate- to high-energy gamma rays are emitted in sufficient intensity to permit estimates of quantities in low- to moderate-density waste packages as large as 208-L drums. Figure 1 shows the ASTM-recommended experimental arrangement for SGS assays. ${ }^{5}$ This figure displays the essential elements required for SGS assays of TRU isotopes in any package size.

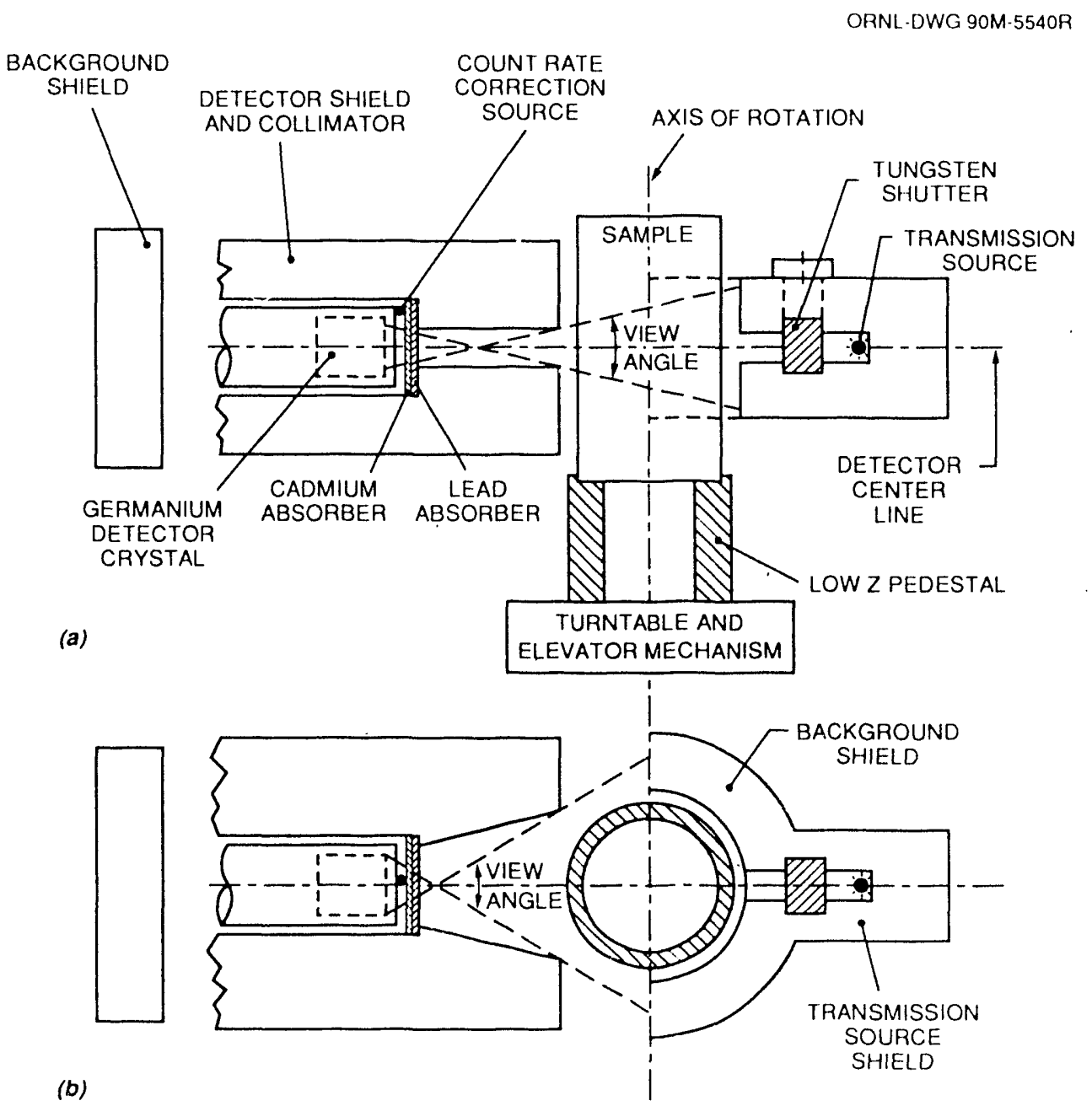

Fig. 1. Schematic arrangement for the segmented gamma-ray scanning system: (a) elevation view and (b) plan view. 
To minimize assay errors due to axial inhomogeneities, assays are performed in segments along a waste package's vertical axis. The effects of radial inhomogeneities are minimized by rotating the drum during the assay measurement. The detector is shielded such that the waste drum can be scanned in segments (i.e., typically 10 to 20). Gamma-ray attenuation is measured for each segment with a transmission source in the indicated geometry of Fig. 1. The energy of this source is selected to match that of the gamma-ray line(s) being measured [e.g., ORNL uses a mixed ${ }^{152} \mathrm{Eu} /{ }^{154} \mathrm{Eu}$ oxide source for its large array of gamma-emitting radioisotopes (50 to $1600 \mathrm{keV}$ ), and ${ }^{75} \mathrm{Se}$ is typically used for ${ }^{239} \mathrm{Pu}$ assays].

State-of-the-art counting electronics allow dynamic counting rate ranges of factors of $10^{4}$ to $10^{5}$ or more; dead-time corrections are measured with a second small, low-energy source positioned near the detector. Waste packages are automatically retated about their "rrtical axes and cycled through the required segment heights with standardized, computer-controlled electronic motors and precision mechanical turntable/elevator hardware. SGS hardware-software packages are commercially available from several manufacturers.

\subsubsection{Applicability to Contact-Handled Transuranic Wastes}

A prime factor that determines applicability of SGS to perform assay measurements of $\mathrm{CH}-\mathrm{TRU}$ waste packages is gamma-ray transmission through the package. Other factors affecting assay measurements include particle self-absorption and nonhomogeneity of the assayed item (i.e., "lumping"). Two conditions must be met to optimize assay results: First, the particles containing the nuclide must be small to minimize self-absorption of emitted gamma radiation. Second, the mixture of material within a package segment must be reasonably uniform to apply an attenuation correction factor comput,d from a single measurement of item transmission through the segment. Variations in item composition and density within a vertical segment lead to indeterminate errors. Such variations should be minimized through strict scrap and waste segregation procedures.

A combination of analytical error analysis ${ }^{5}$ and experimental usage over many years has determined that transmission factors greater than or equal to $0.5 \%$ are required for accurate SGS assays. The physical density of a waste package that this requirement defines depends greatly on the package size [i.e., the radial distance from the gamma-emitting source(s) to detector] and the energy of the gamma rays used for the analysis. Four-liter packages having densities as high as $2 \mathrm{~g} / \mathrm{cm}^{3}$ meet the criterion, while $208-\mathrm{L}$ packages are limited to densities of $0.5 \mathrm{~g} / \mathrm{cm}^{3}$ or less. To ensure compliance with these limits, all current SGS software packages include an automatic warning indicating when the transmission factor for any sector falls below the prescribed limiting value. Routine practice SGS measurement control recommends that the contribution from that sector be calculated based on the lower-limit transmission (e.g., 0.5\%).

The reason for maintaining the assay value, rather than disregarding it, is that most SGS transmission failures occur for only one sector out of the 10 to 20 drum scctors assayed. This sector, on the average, contains only a small fraction of the waste drum's total TRU inventory of gamma-cmitting isotopes. On the average, estimating the TRU content for one, two, or three such failed segments in this fashion results in only a small overall assay error for the waste drum. Other sites (e.g., Hanford) flag such drums for management decision on whether the item should be (1) disassembled, examined, and repackaged or (2) reassayed on a neutron-sensing assay instrument, which is less sensitive to density variations. Because the SGS assay value or a transmiscion failure is truly a 
lower limit (see Subsect. 3.4), passive neutron assays generally provide upper limit assay values (especially for WG plutonium); the combination of SGS and passive neutron assay methods tends to bracket the actual assay value.

Some matrix forms are inherently unsuitable for SGS analysis. Such forms may contain "lumps" of nuclide (i.e., nuclide contained in small volumes of matrix material having a localized density substantially different from the bulk density of the rest of the container). The dimensions of nuclide particles that constitute a lump vary with the energy of the emitted radiation used for the analytical measurement. The possible magnitude of the problem may be estimated from the following example of attenuating effects. A plutonium metal sphere $0.02 \mathrm{~cm}$ in diameter will absorb approximately $4 \%$ of the $414-\mathrm{keV}{ }^{239} \mathrm{Pu}$ gamma rays produced. Approximately $15 \%$ of the $186-\mathrm{keV}$ gamma rays of ${ }^{235} \mathrm{U}$ will be absorbed in a uranium metal sphere of the same diameter.

As mentioned previously, another condition that will cause measurement problems is presented by containers with several irregular regions, highly variable in density, that prevent the calculation of a valid attenuation correction based on the transmission measurement. In case of such a condition, an analytical method less sensitive to nuclide and matrix densities such as PNCC should be employed. Careful inspection of the transmission and nuclide peak areas for each segment may provide clues when a measurement should be suspected. Sudden, discontinuous changes in the transmission values for adjacent segments or high-nuclide-count values for isolated segments are examples of signals indicating possible problem items.

\subsubsection{Instrument Calibration, Standards Preparation, and Implementation}

Recommended DOE facility standard guides for both preparation ${ }^{10}$ and implementation ${ }^{1}$ of SGS standards have been published by ANSI. The latter calls for preparation of (1) the calibration material using intimate and stable mixtures of the TRU isotope with matrix material and (2) a suitable number of calibration standards to cover the anticipated isotopic concentration region of interest (ROI). In the case of ${ }^{239} \mathrm{Pu}$, this range is 5 to $200 \mathrm{~g}$ for 208-L drums. Calibration standards spanning this approximate range are employed at all DOE sites using SGS for WG plutonium assay.

When establishing a calibration curve for the SGS instrument, at least two calibration standards are used for each content code. One standards drum contains a TRU isotopic mass near the low end of the ROI (e.g., $5 \mathrm{~g}$ of ${ }^{239} \mathrm{Pu}$ ), while the other contains a TRU isotopic mass near the high end of the ROI (e.g., $200 \mathrm{~g}$ of ${ }^{239} \mathrm{Pu}$ ). Both drums contain waste stream matrix mixtures and densities designed to simulate the waste streams. Some sites use more than the two drums described above to ensure a proper calibration constant. Other sites have measurement control programs that require multiple measurements of standards drums by the assay instrumeint both before and after each measurement session.

Acceptable ranges for calibration data are specified in the operating procedures (e.g., ORNL accepts a variance of $\pm 5 \%$ ). If an assay measurement falls outside the acceptable range, no production assay measurements are performed until the issue has been resolved. Operators will contact a designated NDA expert for consultation. 


\subsubsection{Operator Training Requirements and Practices}

Present-day commercial SGS systems, such as the Canberra models, are highly automated and computer-based. The instruments are computer-controlled using relatively interactive (i.e., "user-friendly") software. Only trained personnel are allowed to operate the assay equipment. Personnel are qualified according to DOE guidelines. ${ }^{11}$ Each site provides a specialized training program for NDA instrument operators. The operators are directed and/or assisted by a designated site NDA expert. Expertise is attained by education and experience.

\subsubsection{Assay Procedures}

ASTM assay procedures cited in ref. 5 are recommended for use at all DOE facilities. These procedures stress usage of proper calibration standards, proper equipment and equipment setup, avoidance of practices (such as misalignment of the waste package) known to result in inaccurate assays, attention to proper record keeping and equipment maintenance, and safe operation of the equipment. At present, an extensive upgrade of these ASTM guidelines (i.e., SGS section) by a subcommittee of ASTM Committee C-26 is in progress. This revision, tentatively titled "Nondestructive Assay of Special Nuclear Material in Low Density Scrap and Waste by Segmented Passive Gamma-Ray Scanning," is being written to cover appropriate operating practices for tuday's generation of commercially available SGS units. The subcommittee members are involved in NDA activities throughout the DOE complex (e.g., subcommittee members include personnel from RFP, ORNL, LANL, and Hanford) as well as in private industry. As a result, DOE SGS installations will be aware of these new, more explicit and extensive standards before they are officially promulgated.

\subsubsection{Assay Precision, Bias, and Detection Limit}

Assay precision is generally taken to mean measurement repeatability. In the case of typical SGS systems operated and calibrated according to the recommended procedures, repeatability of results is limited only by statistical counting errors. Counting statistics, in turn, are a strong function of TRU isotopic loading and counting time.

Reference 4 discusses SGS precision and bias in detail, a summar of which follows. The precision of an SGS assay is a function of the precision of the $\mathrm{pt}$. $\mathrm{k}$ areas measured for each segment. The precision of an assay is normally better when the following conditions can be obtained:

1. increased count time,

2. high-transmission source activity, and

3. low attenuation for gamma radiation in the energy range of interest.

Table 2 lists SGS assay precisions for low-density wastes. Certain matrices (such as graphite molds and cemented insulation whose densities are above the prescribed SGSapplicability limit of $0.5 \mathrm{~g} / \mathrm{cm}^{3}$ for $208-\mathrm{L}$ paci.ages) and drum handling (homogeneity of calibration standards may be jeopardized) can have a deleterious effect on assay precision. ${ }^{5}$ 
Table 2. Segmented gamma scanner assay precisions for low-density wastes contained in a 208-L drum

\begin{tabular}{cc}
\hline $\begin{array}{c}\text { Weapons-grade plutonium } \\
(\mathrm{g})\end{array}$ & $\begin{array}{c}\text { Precision } \\
(\%)\end{array}$ \\
\hline 1 & \pm 100 \\
10 & \pm 10 \\
30 & \pm 3 \\
\hline
\end{tabular}

(Table 2 values reflect the assumption that the ASTM guidelines given in ref. 5 were adhered to in acquiring the data.)

The precision of an assay is not strongly related to the measurement item's adherence to ideal matrix and nuclide density assumptions. However, measurement bias depends primarily on the adherence of the measurement item to the assumptions of small particle size and homogeneity. Negative bias will be encountered when the nuclide is present in lumps that attenuate their own radiation to a greater extent than the surrounding material. Positive bias can result from low-transmission items with over-corrected end effects. Items containing high-density areas may be biased (either high or low) or be unbiased deperding on the relative position of the high-density area and the nuclide of interest. In the majority of measurement situations, however, when biases exist, measurement results are expected to be lower than true values.

Several SGS and destructive assay comparison studies of several waste forms indicate SGS assay biases of $10 \%$ or better at the $95 \%$ confidence level. ${ }^{12}$ Assay biases for low-density waste matrices contained in 208 - L drum packages are $5 \%$ or less. In small package applications (based on numerous safeguards and nuclear materials accounting applications), SGS assay biases of better than $0.5 \%$ have been reported. ${ }^{12}$ The basic assay formalism associated with the SGS method (i.e., transmission correction and the use of small segments) is conducive to very accurate results if recommended procedures are correctly followed. Heterogeneous matrices and isotopic concentration can have a severe effect on assay bias for a given waste drum. Table 3 summarizes SGS assay biases for two types of wastes.

Table 3. Segmented gamma scanner assay biases

\begin{tabular}{lc} 
Waste type & $\begin{array}{c}\text { Biases } \\
(\%)\end{array}$ \\
\hline $\begin{array}{l}\text { Heterogeneous salts } \\
\text { Low-density (general laboratory wastes) }\end{array}$ & $10^{a}$ \\
\hline${ }^{a}$ Based on assay of a number of $4-\mathrm{L}$ waste packages prior to \\
placing in a 208-L drum.
\end{tabular}

(Table 3 values reflect the assumption that the ASTM guidelines given in ref. 5 were adhered to in acquiring the data.)

The SGS assay limit of detection for typical applicable wastes and standard counting times in current routine use in DOE facilities (i.e., 30 min or less per assay measurement) is about $5 \mathrm{~g}$ of WG plutonium. This is based on $30 \%$ assay precision. Usually SGS assays are performed only on 208-L drums when screening indicates that $10 \mathrm{~g}$ or more of WG plutonium is present. 


\subsubsection{SGS Assay Results Comparisons}

As an NDA comparison (refereed) technique for an assessment of SGS assay of RFP molten salts, calorimetric assay measurements of heterogeneous molten salt residues provided a total assay value for plutonium and americium. ${ }^{12}$ Because the relative amount of heat produced by the americium in these samples was typically $50 \%$ or more, reliable interpretation of the calorimetry measurements depended on an accurate determination of the americium:plutonium ratio. Gamma-ray spectral isotopic analysis coupled with calorimetry was performed at Mound on nine cans of molten salt that were subsequently returned to the RFP for dissolution and solution quantification. Results of the Mound measurements showed relative standard deviation ranges from 0.032 to $0.50 \%$ for plutonium values and from 0.23 to $0.39 \%$ for americium values. No biases or statistical differences between pairs of measurements were noted.

\subsubsection{NaI (Low-Resolution) Assays}

Both transmission-corrected and -uncorrected $\mathrm{NaI}$ assay units are used in DOE facilities. The transmission-uncorrected units are used, for example, at RFP for low-density wastes containing up to $20 \mathrm{~g}$ of plutonium. At the Hanford Z Plant, waste packages are screened for TRU content at the point of origin. The final reported assay value for a waste container is determined by another method such as SGS or PAN.

The $\mathrm{NaI}$ transmission-corrected assay instruments are special function units that service isolated waste streams producing a single type of waste under generally constant conditions. Typically, these $\mathrm{NaI}$ units consist of five individual collimated NaI detectors mounted at different heights that view a rotating drum and produce a five-segment assay. Transmission source geometry is similar to that shown in Fig. 1. The pertinent NDA guidelines outlined by the $\mathrm{ASTM}^{5}$ are applied to these systems in a fashion similar to that described for SGS units. A two-window pulse height analysis is performed to correct for ${ }^{244} \mathrm{Am}$ and fission product interferences, and software indicators flag segments containing excessive americium or fission product amounts.

Calibration standards are carcfully chosen for the particular waste stream being monitored, and assays are performed in a fashion similar to SGS assays. These units produce, on the average, reliable results as determined by numerous quantitative comparisons with SGS and PAN assays of the same wastc drums. ${ }^{13}$ Analytical studies of assay biases for these systems indicate $\pm 10 \%$ levels of bias. This has been verified by SGS and PAN comparisons of a large number of drums assayed with these NaI systems. ${ }^{13}$ Assay standard practices and procedures published by ANSI are strictly followed. ${ }^{5,10}$ Duplicate assays with SGS or PAN (performed at the certification facility) provide additional assurance that proper TRU assay values are being generated with these systems.

\subsection{RADIOCHEMICAL METHODS}

The basic application of radiochemical methods in TRU waste assays is in quantifying radioisotopic content of process liquid or sludge waste forms. Before final drying or cementation, a batch of process sludge is contained in a single large tank. The sludge is then mixed for a sufficient period of time to ensure a homogenous mixture. This mixture is then sampled at several points while circulating, and the samples are subjected to routine radiochemical processing and analysis (i.e., precipitation and separation 
followed by alpha andior gamma spectrometry). The prepared aliquot samples are assayed in a standard alpha spectrometer. In the cases of higher-activity sludges, these samples are assayed using another method (e.g., passive gamma-ray spectroscopy). Assays of samples obtained from individual sludge drums may also be performed.

Using standard analyses, one can determine the individual TRU isotopic activities: ${ }^{239} \mathrm{Pu}$, total plutonium (WG plutonium), and ${ }^{241} \mathrm{Am}$. These aliquot sample activities are then used to determine the original batch TRU activity on an individual isotopic basis. By proper accounting for any volume reduction or increase produced in the drying or cementation process, one can then use these batch activities to determine an individual 208-L drum's specific plutonium and americium content simply by weighing the drum and accounting for the amount of original batch sludge that was deposited in that particular drum. Accurate final drum assiays clepend on following the procedure outlined in a careful manner with maintenarce of a homogeneous mixture during both the critical-sampling and drum-filling stages.

ANSI standard test methods describe the radiochemical standard aliquot sampling procedures used in the DOE facilities. ${ }^{14-16}$ Assay standards are prepared and used as indicated in the standard test methods. Sampling, weighing, and handling of the sample are done under conditions that ensure representative sampling of the lot or batch. A lot or batch is defined as any quantity of solution that is uniform in isotopic, chemical, and physical characteristics by virtue of having been mixed in such a manner as to be thoroughly homogeneous. All containers used for a lot or batch are positively identified as containing material from a particular homogeneous solution. Assay biases at the final drum-filling stage are difficult to estimate because they depend primarily on the maintenance of homogeneous mixtures during the sampling, drying/cementing, and final drum-filling stages.

\subsection{PASSIVE NEUTRON COINCIDENCE COUNTING ASSAYS}

\subsubsection{Overview}

The PNCC assays include those conducted on small packages (that are summed to give the final reported assay value for a waste container) and the passive poitin of the PAN assay system (detailed in Sect. 3.5). The PNCC method for determination of plutonium assay in product materials has been used for safeguards verification purposes within the DOE complex for more than 20 years. It has also been applied to the assay of TRU-bearing wastes and scraps for many years (ref. 1, Subsects. 20-28). In addition, NDA techniques acceptable to the NRC for assay of wastes and scraps (including PNCC) have been published. ${ }^{2}$ These standards and regulatory guides are used by DOE to ensure proper application of PNCC to scrap and waste assays. In fact, DOE laboratories, primarily LANL, have been largely responsible for the development of PNCC as a reliable assay technique not only for scrap and product but also for TRU wastes.

The prototypical PNCC is comprised of a high-efficiency neutron detector large enough to accommodate the waste package of interest. It operates by detecting the number of time-correlated neutrons being emitted spontaneously by the assay item. In fission events, emissions of $2,3,4,5$, etc., neutrons occur simultaneously, and the detection of two or more of these in time coincidence serves to identify the original fission event within the material being measured. Specialized counting electronics (e.g., shift register) have been devised to accomplish and to record these measurements. These are discussed in detail in refs. 17 and 18. 
Any TRU isotope that undergoes spontaneous fission at a measurable rate can be quantified by PNCC. Comprising this category are the even isotopes of plutonium, curium, and californium. Most commonly within the DOE complex, the different grades of plutonium [i.e., WG, reactor grades (RGs) of different isotopic compositions, and heat source grade (HSG)] are quantified by coincidence counting of the included mixture of even isotopes of plutonium: predominantly ${ }^{240} \mathrm{Pu}$ for WG and RG and ${ }^{238} \mathrm{Pu}$ for HSG. Thus, with knowledge of the plutonium isotopics, the observed coincidence rates can be interpreted to yield total plutonium mass.

\subsubsection{Applicability to Contract-Handled Transuranic Wastes}

The primary requirement for application of PNCC to CH-TRU waste assay is knowledge of the included isotopics, since normally the quantity of interest is the total elemental mass (i.e., total plutonium mass) rather than the even isotope masses only. In addition, the wastes should not include mixed-element spontaneous fission emitters. For instance, it is undesirable to have curium and californium isotopes present in the same assay item containing plutonium isotopes. Most DOE CH-TRU wastes contain plutonium even-isotope spontaneous fission emitters. A typical average WG plutonium isotope mix contains $5.8 \%$ of ${ }^{240} \mathrm{Pu}$. Plutonium-240 is responsible for more than $99 \%$ of coincidence neutrons detected in typical WG plutonium wastes.

\subsubsection{Instrument Calibration, Standards Preparation, and Implementation}

Calibration of PNCC instruments, similar to SGS, is obtained by establishing a curve of instrument response vs isotopic mass. ${ }^{1,5}$ Applying standards that are representative of the materials being measured, a minimum of four calibration points are used over the mass range of interest. Within each content code or waste category, a measurement is made of the variation due to interference effects within the boundaries defining the limits of that category. For calibration standards, containers are used that are identical to those employed for the scrap or waste with contents that are representative of the range of matrix conditions to be encountered. It is not recommended to extrapolate beyond the calibration range established during instrument calibration. Encapsulated ${ }^{252} \mathrm{Cf}$ sources such as those used at ORNL for passive PAN calibration are available to be used for PNCC calibration purposes.

Acceptable ranges for calibration data are specified in the operating procedures. If assay measurement values fall outside the acceptable range, no production assay measurements are performed until the issue has been resolved. Operators contact a designated NDA expert for consultation.

\subsubsection{Operator Training Requirements and Practices}

Present-day commercial PNCC systems such as the JOMAR or National Nuclear models are highly automated computer-based systems. The instruments are computer-controlled using relatively interactive (i.e., "user-friendly") software. Only trained personnel are allowed to operate the assay equipment. Personnel are qualified according to DOE guidelines. ${ }^{11}$ 
Each site provides a specialized training program for NDA instrument operators. The operators are directed and/or assisted by a designated site NDA expert. Expertise is attained by education and experience.

\subsubsection{Assay Procedures}

Specific ASTM assay procedures are recommended for use at all DOE facilities. ${ }^{5}$ These procedures stress usage of proper calibration standards, proper equipment and equipment setup, avoidance of practices (such as misalignment of the waste package) known to result in inaccurate assays, attention to proper record keeping and equipment maintenance, and safe operation of the equipment.

An extensive upgrade of the ASTM's PNCC section ${ }^{5}$ by a subcommittee of ASTM Committee C-26 is in progress (similar to the current revision of the SGS section). This revision, tentatively titled "Passive Neutron Coincidence Counting of Special Nuclear Material in Low Density Scrap and Waste," is being written to cover appropriate operating practices for today's generation of commercially available PNCC units. The subcommittee members are involved in NDA activities throughout the DOE complex (e.g., subcommittee members include personnel from RFP, ORNL, LANL, and Hanford) as well as in private industry. As a result, DOE installations that employ PNCC instruments will be aware of these new, more explicit and extensive standards before they are officially promulgated.

\subsubsection{Assay Precision, Bias, and Limit of Detection}

Most PNCC units are used to assay small packages (i.e., 4-L size) that are then placed into larger waste containers such as 208-L drums. Assuming proper administrative control of drum filling, this practice greatly reduces the assay errors associated with all PNCC performance effects except counting statistics and isotopics. Additional errors caused by sysiem multiplication or system dead time are significant only when strong neutron sources are present.

Sources of assay biases and measurement uncertainties include:

1. Counting statistics. These can be a significant source of error at both extremes of count rate measurement uncertainty-at very low count rates for all assay conditions and at very high count rates (i.e., increased assay bias) when the rate is primarily due to a strong (i.e., $\alpha, \mathrm{n}$ ) internal source or induced fissions.

2. Isotopics. For WG plutonium, waste assay errors produced by uncertainties in actual plutonium isotopics are $3 \%$ or less based on use of historic average WG plutonium isotopics. Uncertainties in the measurement of the isotopic composition (generally considered to be unbiased) increase the uncertainty of the assay value.

3. System multiplication (or induced fissions). Generally, this is a problem when fairly large plutonium amounts are present in conjunction with strong (i.e., $\alpha, \mathrm{n}$ ) sources within the same drum (i.e., measurement value is greater than actual value). This phenomenon is a source of potential bias producing uncertainty in the assay value. Multiplication effects should not be significant when TRU gram loadings are low and waste volumes are large.

4. System dead time. This can be a problem when strong neutron sources are present (i.e., measurement value is less than actual value). This phenomenon is a source of potential bias with an associated uncertainty. 
5. Calibration. Typically, assay uncertainties produced by uncertaintics in calibration are $3 \%$ or less.

6. Matrix effects. Matrix effects include neutron poisons (e.g., boron and cadmium) and other neutron emitters [i.e., species that spontaneously fission or have strong $(\alpha, \mathrm{n})$ reactions] and neutron moderators. See ref. 6 for a discussion of moderator error estimation techniques.

Tables 4 and 5 provide a summary of PNCC assay error contributions and assay biases, respectively, for some typical waste forms.

Table 4. Summary of passive neutron coincidenoc counting assay error contributions

\begin{tabular}{lc}
\hline Error contribution & $\begin{array}{c}\text { Typical errors } \\
(\%)\end{array}$ \\
\hline System multiplication & \pm 5 \\
System dead time & \pm 3 \\
\hline
\end{tabular}

Table 5. Passive neutron coincidence counting assay biases

\begin{tabular}{|c|c|}
\hline Counting statistics & $\begin{array}{c}\text { Variance } \\
(\%)\end{array}$ \\
\hline \multicolumn{2}{|l|}{ Weapons-grade plutonium, $\mathrm{g}$} \\
\hline 1 & \pm 50 \\
\hline 10 & \pm 10 \\
\hline 30 & \pm 5 \\
\hline 100 & \pm 3 \\
\hline Isoropics & \pm 3 \\
\hline Calibration & \pm 3 \\
\hline Matrix (low-density) & $\pm .5-20$ \\
\hline
\end{tabular}

Estimates of PNCC assay uncertainty can be calculated by standard error propagation techniques from the various bias contribution variances. The grams of plutonium calculated by PNCC are a function of net passive neutron count rate, or gross neutron coincidence count rate minus accidental neutron coincidence rate (SIGP), system multiplication (SYSMULT), system dead time (SYSDT), isotopics (ISOP), calibration (CALIBP), and moderator index (MI).

For $30 \mathrm{~g}$ of plutonium, the uncertainty in the $30 \mathrm{~g}$ of plutonium is given by:

$$
\begin{aligned}
\mathrm{W} & =\left[(\text { SIGP })^{2}+f(\text { SYSMULT })^{2}+f(\text { SYSDT })^{2}+f(\text { ISOP })^{2}+f(\text { CALIBP })^{2}+f(\mathrm{MI})^{2}\right]^{1 / 2} \\
& =\left[(0.05)^{2}+(0.05)^{2}+(0.03)^{2}+(0.03)^{2}+(0.03)^{2}+(0.20)^{2}\right]^{1 / 2} \\
& =0.218 \text { or } 21.8 \%
\end{aligned}
$$

The passive mass assay value reported by the PNCC assay algorithm would then be:

$$
\text { passive mass }(\mathrm{g})=30.00) \pm 6.55
$$


Bias of PNCC assays is attributed primarily to the presence of $(\alpha, n)$ reactions in the chemical form of the plutonium-bearing material or in the waste material itself.

Interferences due to $(\alpha, \mathrm{n})$ reaction contributions result in systematically high estimates for the plutonium content. The neutrons present in the assayed item due to the $(\alpha, n)$ reactions induce additional fissions that are not effectively factored out of the PNCC calculational algorithm.

Overall neutron production rates for several of the more common TRU isotopes and several of the more common matrices that produce significant $(\alpha, n)$ reactions have been published. ${ }^{19}$ For example, WG plutonium, which has an average alpha energy of $5.15 \mathrm{MeV}$, produces approximately $2 \mathrm{n} \cdot \mathrm{s}^{-1} \cdot \mathrm{mCi}^{-1}$ alpha in an oxide matrix and $215 \mathrm{n} \cdot \mathrm{s}^{-1} \cdot \mathrm{mCi}^{-1}$ alpha in a fluoride matrix. Plutonium-238 and ${ }^{24} \mathrm{Am}$, which have an average alpha particle energy of $5.5 \mathrm{MeV}$, produce approximately $2.5 \mathrm{n} \cdot \mathrm{s}^{-1} \cdot \mathrm{mCi}^{-1}$ alpha in an oxide matrix and approximately $310 \mathrm{n} \cdot \mathrm{s}^{-1} \cdot \mathrm{mCi}^{-1}$ alpha in a fluoride matrix. These values are representative of pure chemicals and alloys. Neutron production rates for waste materials will be less because the TRU isotopes are more widely dispersed and because the alpha particles are less likely to encounter a productive target.

The more usual $(\alpha, n)$ reactions that can cause passive assay concerns consist of normal WG plutonium in which a sizeable fraction of the plutonium is chemically bound either to fluorides or in a salt mixture containing aluminum or magnesium. Typically, metal oxide or nitrate forms of TRU isotopes (that produce approximately 0.7 to $2 \mathrm{n} \cdot \mathrm{s}^{-1} \cdot \mathrm{mCi}^{-1}$ alpha) present no problems for passive neutron assays (both passive PAN and PNCC). In practice, rates ranging to $20 \mathrm{n} \cdot \mathrm{s}^{-1} \cdot \mathrm{mCi}^{-1}$ alpha do not decrease passive assay precisions drastically as long as the alpha sources present are only those associated with WG or RG plutonium. However, waste streams that include additional ${ }^{241} \mathrm{Am}$ can be difficult to assay passively even if the TRU chemical form is the oxide.

\subsection{PASSIVE-ACTIVE NEUTRON ASSAY SYSTEM}

\subsubsection{Overview}

The PAN assay system consists of two independent assay units: passive and active neutron, a combination that, within a common system, provides a urique set of information. The passive assay portion of the PAN method described in this subsection is an adaptation of the PNCC method using "self-measurement" matrix corrections. Two complete passive assay detection methods are maintained with separate counting electronics. Two detection methods are used separately or in combination depending on the neutron count rate. The passive coincidence measurement provides quantitative information on even isotopes (such as ${ }^{240} \mathrm{Pu}$ ) present in the waste container. The passive singles neutron count rate (i.e., the difference between the total neutron rate and that due to spontaneous fission events) provides semiquantitative information on alpha particle emitters (such as ${ }^{242} \mathrm{Am}$ ) present in the waste container. The active assay provides quantitative information on the ${ }^{239} \mathrm{Pu}$ and other fissile isotope constituents. See refs. 6 and 20 for a more complete description of the system.

For WG plutonium, the passive coincidence and active assays provide independent total plutonium assay values. This fact has been extremely important in verifying the accuracy or determining the bias of the PAN assay measu ement technique (presented in ref. 6). This formalisi.. has also been verified by extensive comparisons of both passive and active neutron assays with SUS. ${ }^{\text {is }}$ 
The PAN assay system has been developed for both drums and boxes (see Sect. 5 for a discussion of box PAN assay systems). For these relatively large waste containers, effects of the waste material (i.e., matrix) on the neutron signals observed cannot be neglected.

\subsubsection{Instrumentation}

\subsubsection{Passive Assay Portion}

The passive portion of the PAN assay system utilizes the two types of detection packages to determine an MI that, in turn, is used to determine a correction to the assay calculation that will account for matrix characteristics and optimize counting statistics depending on the actual relative neutron sources encountered. For low count-rate waste containers, all counts detected by the neutron detector packages are summed to yield the lowest assay limit of detection possible. All detector count rates (acquired by both bare and shielded detectors) are summed electronically to obtain a "system totals" neutron detection efficiency of approximately $12 \%$.

For waste containers with higher plutonium loadings (e.g., $100 \mathrm{~g}$ or more) coupled with strong $(\alpha, n)$ backgrounds, the cadmium-shielded detectors are summed independently, and the "shielded totals" count rate is formed with a resulting neutron detection efficiency of approximately $3 \%$. However, this detection package possesses a much faster "die-away" or "neutron-collection" time (approximately six times faster than that of the slower system totals) that is approximately $15 \mu \mathrm{s}$. At low count rates, the slower collection time is of no consequence [i.e., accidental coincidences due to $(\alpha, n)$ reactions are small]; thus the system totals provides not only a more sensitive but also a statistically more precise passive assay measurement. At higher data collection rates, the faster die-away time of the shielded totals gains a higher precision than the neutron detection efficiency. As a consequence, at high neutron count rates the shielded totals coincidence rate is used to obtain the more precise passive assay measurement value.

The cross-over count rate (i.e., the count rate at which the assay measurement value obtained by the shielded totals supplants the system totals) has been experimentally determined to be approximately 2000 counts per second (system totals count rate), and this value is used in the assay algorithm. Within a substantial range either system coincidence or shielded coincidence rates provide precise assay values. Many data comparisons have been performed in this cross-over region to verify the self-consistency between the two coincidence measurements. ${ }^{13}$

\subsubsection{Active Assay Portion}

The active portion of the PAN system performs a high-sensitivity, pulsed thermal neutron interrogation assay of waste drums. A small $14-\mathrm{MeV}$ neutron generator placed within the assay chamber between the waste drum and moderating walls provides short pulses (i.e., 5 to $10 \mu \mathrm{s}$ ) of high-energy interrogating neutrons (Fig. 2). In approximately 0.5 ms all original fast neutrons in this interrogating pulse have been thermalized by multiple collisions with the graphite and polyethylene walls and moderating materials within the waste drum. This "thermalized interrogating pulse" persists (i.e., $\mathrm{T}_{12}$ about $400 \mu \mathrm{s}$ ) for

some time. During this time, induced fissions within the waste drum are produced, primarily in ${ }^{23 y} \mathrm{Pu}$ or other fissile isotopes. These events, in turn, result in prompt fïssion, spectrum neutrons being emitted by each fissioning nucleus. 
The cadmium-shielded detection packages have been designed to reject an external thermal neutron flux to 1 part in $10^{7}$ but to respond sensitively to fission spectrum neutrons. The summed shielded detector packages shown in Fig. 2 detect about 3\% of all induced fission events that are produced within typical waste drums.

ORNL-DWG 90M-5541

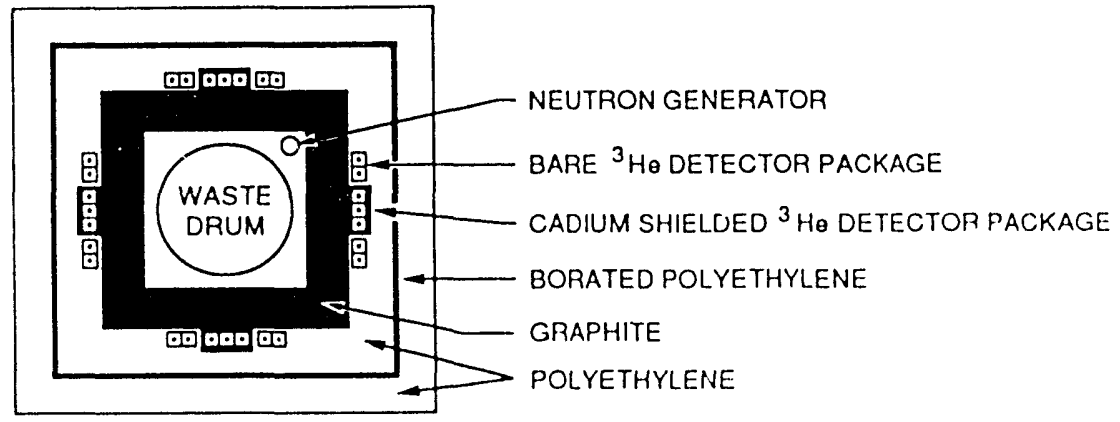

Fig. 2. Basic cross-sectional view of a typical Los Alamos National Laboratory passive-active neutron detection system showing the schematic "interwoven" layout of the two distinct types of neutron detection packages (i.e., bare ${ }^{3} \mathrm{He}$ and cadmium-shielded ${ }^{3} \mathrm{He}$ detector tubes).

An additional measurement feature (shown in Fig. 2 but discussed at length in ref. 6) is the set of thermal flux monitors: one cadmium-shielded and collimated and the other bare. They are also positioned inside the assay chamber between the waste drum and the moderating walls. The ratio of these flux monitors is highly sensitive to the total neutron absorption characteristics of the waste drum contents. This ratio is used to form a drum absorber index (AI) (see Subsect. 3.5.3.)

\subsubsection{Passive-Active Neutron Assay Matrix Corrections}

Two types of matrix effects can interfere with the active neutron measurements: absorption and moderation. ${ }^{6}$ The absorption effects occur almost entirely as an attenuation of the interrogating thermal neutrons caused by the presence of various neutron poisons withir the waste matrix (e.g., boron, cadmium, chlorine, etc.). Moderation effects occur at two stages of the measurement. The original burst of $14-\mathrm{MeV}$ neutrons can be moderated to a considerable extent during passage through the waste matrix. Generally, this results in a larger thermal neutron interrogation flux than would have been produced in the absence of matrix. After the interrogation flux has produced fission reactions within the waste matrix, the same moderating materials can attenuate the prompt-fission signal neutrons resulting in a decrease in observed response relative to the no-matrix case. This attenuation of signal fission-neutrons also is the primary matrix effect for the passive measurement.

The approach to matrix corrections has been to base corrections on measured quantities determined as adjuncts to the primary active and passive TRU assay measurements. The systematic matrix correction algorithm is based on an analytic fit to assay measurements obtained for different positions of the source within a matrix drum. 
These analytic fits then provide estimates of uncertainty for the active and passive assay data.

The absorption matrix correction approach used by the PAN system employs a ratio of an unshielded in-chamber flux monitor to a cadmium-collimated, in-chamber flux monitor (designated the barrel flux monitor). This ratio is termed the AI. The barrel flux monitor detects those neutrons that have undergone drum matrix interactions. The ratio of the monitors strongly reflects the neutronic properties of the matrix:

$$
\mathrm{AI}=\frac{[\text { flux monitor response }(0.7 \text { to } 4.7 \mathrm{~ms})]}{[\text { barrel flux monitor response }(0.7 \text { to } 4.7 \mathrm{~ms})]}
$$

The MI depends upon the responses of the two detection systems (i.e., cadmiumshielded and bare) to moderated neutrons. The shielded detectors are insensitive to thermal neutrons, while the bare detectors are very sensitive to the thermal neutron flux. In turn, the thermalized fraction depends very strongly on the moderator density of the matrix. To use this relationship in obtaining matrix correction factors, the ratio is normalized so that a value of zero is obtained when no moderator is present; in addition, a small correction is made to account for self-absorpti in effects. An example of an MI calculation follows:

$$
M I=\left\{1-[(\text { shielded totals }) /(\text { system totals })] / A_{0}\right\} \times\left\{A_{1}+A_{2} \times \ln (A I)\right\} .
$$

The term within the first set of brackets is the basic raw spectral data; the term within the second set of brackets is the correction term for matrix absorption effects. The same MI values are used for both active and passive matrix corrections.

To obtain data to construct the analytical models of matrix correction factors, 19 simulated waste matrices were fabricated; ${ }^{6}$ active and passive calibration standards were placed in known locations throughout the waste matrix drums. Both active and passive assay matrix response measurements were obtained as a function of location (i.e., radius, $r$, and height, $z$ ) of the standards. The resulting matrix response values varied smoothly as a function of $\mathrm{r}$ and $z$. These studies determined that the systematic effects are due only to gross neutron absorber and moderator amounts and are independent of the actual nature of the materials themselves. That is, a drum filled with Rashig rings (i.e., borated glass) produces the same responses as a drum filled with vermiculite mixed with an equally absorbing amount of borax.

Most of the observed distributions have been found to fit a power law:

$$
y=A+B \mathrm{r}^{N}
$$

where $A, B$, and $N$ are the fit parameters and $\mathrm{r}$ is the drum radius. Volume-weighted average values were calculated using this equation represcnting the most probable 
measurement result for either a totally uniform or a totally random distribution of source material within the matrix.

The matrix correction factor (MCFA) for an active assay measurement is a function of the $\mathrm{AI}$ and $\mathrm{MI}$ values:

$$
\operatorname{MCFA}=\operatorname{MCFA}(\mathrm{AI}) \times \operatorname{MCFA}(\mathrm{MI})
$$

The MCFA values were fit to the power law as a function of their AI values for the 19 simulated waste matrices. The following sets of equations describing the absorption portion of the active assay matrix correction factor were obtained for one PAN system:

$$
\operatorname{MCFA}(\mathrm{AI})=1.00
$$

for the AI less than or equal to 2.72 and

$$
\operatorname{MCFA}(\mathrm{AI})=0.54 \times(\mathrm{AI})^{0.612}
$$

for the AI greater than 2.72. The moderator portion, MCFA(MI), of the active assay matrix correction factor is obtained by dividing the total measured MCFA values by the calculated MCFA(AI) values obtained in these two equations.

The analytic representation of these data is thus of the form

$$
\operatorname{MCFA}(\mathrm{MI})=1.00
$$

for the MI less than or equal to 0.40 and

$$
\operatorname{MCFA}(\mathrm{MI})=0.483 \exp [1.817(\mathrm{MI})]
$$

for the MI greater than 0.40 . The passive neutron matrix corrections are determined by systematic drum matrix measurements in a manner similar to the active measurements discussed previously. The passive matrix correction factors (MCFPs) are a strong function of the MI.

The MCFP analytic fits to the four independent quantities measured during a passive assay scan are:

$$
\operatorname{MCFP}(\text { system totals })=1.00
$$


for the MI less than or equal to 0.355 ,

$$
\operatorname{MCFP}(\text { system totals })=-0.16+3.28(\mathrm{MI})
$$

for the MI greater than 0.355 ,

$$
\begin{gathered}
\text { MCFP(shielded totals })=1 /[1-\mathrm{MI}] \\
\mathrm{MCFP}(\text { system coincidence })=[(0.5967) /(1-\mathrm{MI})+0.4187]^{2} \text {, and } \\
\mathrm{MCFP}(\text { shielded coincidence })=[(0.8902) /(1-\mathrm{MI})+0.2337]^{2}
\end{gathered}
$$

The matrix correction equations given above are contained in the present PAN assay systems algorithms used throughout DOE. Some sites perform additional matrix-dependent corrections to the assay results (see Subsect. 3.5.9).

Figure 3 shows the MI (see ref. 6 for detailed discussion of the MI) obtained with mock matrix drums containing various hydrogen densities spanning the region of interest for general CH-TRU wastes. As can be seen, the MI varies smoothly with average hydrogen density within a 208-L drum. Sludges display one of the highest average hydrogen densities with correspondingly high MIs (i.e., 0.4 to 0.8 ). Lightly moderating matrices such as combustibles have MIs falling typically in the 0.1 to 0.3 region, and miscellaneous metals matrices (generally containing no moderating materials) have measured MIs near 0 .

ORNL-DWG $90 \mathrm{M}-5542$

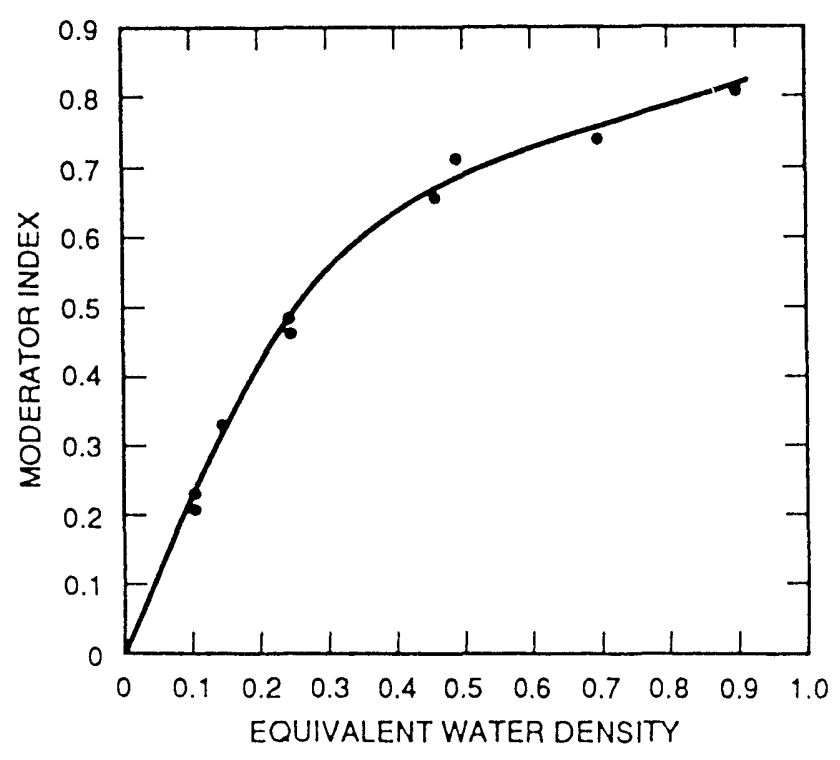

Fig. 3. Moderator index measured for passive-active neutron system using the detector ratio method. 
Figure 4 shows the actual MCF (see ref. 6 for detailed discussion of the MCF) data for the PNCC portion of the PAN system as implemented at INEL, Hanford, and the SRS. The MCF value is the multiplicative factor required to normalize a given matrix measurement to the empty drum level of PNCC sensitivity. As can be seen, the MCF value varies smoothly as a function of the MI; Fig. 4 can be used to estimate typical MCF values:

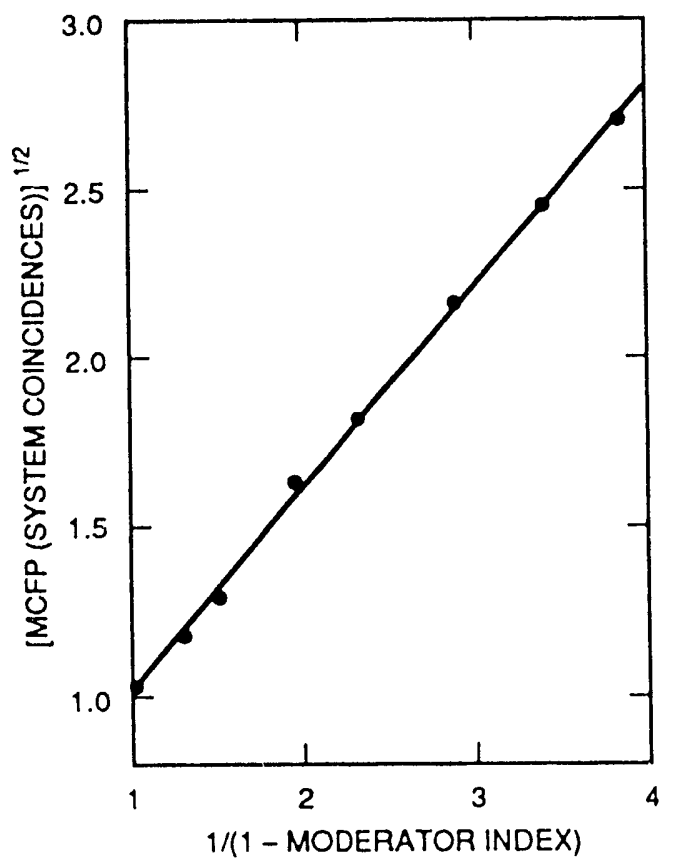

Fig. 4. Use of the moderator index to determine passive neutron coincidence matrix correction factors for a passive-active neutron system.

1. miscellaneous metals, $\mathrm{MCF}=1.0$ (i.e., same sensitivity as with empty drum),

2. combustibles matrix, $\mathrm{MCF}=1.35$, and

3. sludges, $\mathrm{MCF}=3.6$.

The MCF range observed for a 3000-drum CH-TRU sludge assay campaign at INEL was 1.8 to 10.0 .

When performing PNCC assays of highly moderating matrices such as sludges, measurement of an MCF value is essential for accurate assay results to be obtained. A "calibration" based on a "typical" sludge drum would result in assay errors of hundreds of percent for some drums because of the large hydrogen density variations observed.

Figures $5(a)$ and $5(b)$ show plots of the systematic active assay correction factors. As can be seen in Figs. 5(a) and 5(b), some waste materials require no matrix correction (relative to a standard response measured in an empty drum). Examples of these waste matrices are cellulose-based combustibles, graphite molds and scarfings, aluminum scrap, dry to moderately wet dirt, and silica. 

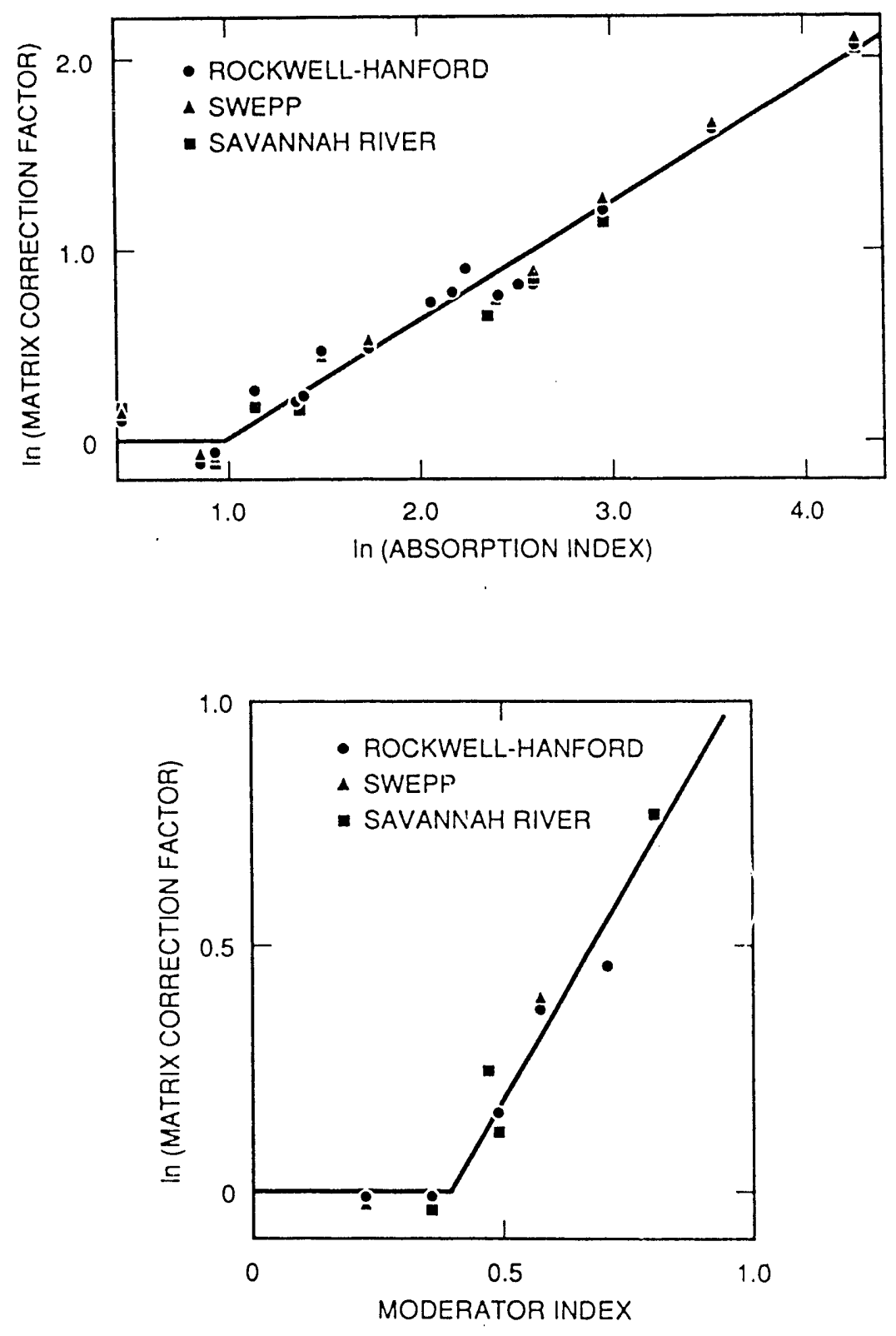

Fig. 5. Passive-active neutron system active assay matrix correction factors measured at IIanford, Idaho National Engincering Laboratory, and the Savannah River Plant with a set of 20 standard matrix drums.

\subsubsection{Assay Algorithm and Data Acquisition System}

All PAN units utilize the same basic assay algorithm. At present, all drum-size units are equipped with IBM/PC-based data acquisition systems as described in ref. 21 . The system operating program (NEUT) controls all data acquisition and contains the assay algorithm.

Each data acquisition consists of sequential active and passive neutron assays preceded by a user interactive initialization stage in which drum identification, content code information, drum weight, etc., can be entered from the PC keyboard, from a bar 
code reader, or from an RS-232 port by direct interaction with a site's data management computer. The weight of the drum's contents is used in calculating the assay value in nanocuries per gram; this differentiates between TRU and non-TRU wastes. The content code input is used to flag difficult-to-assay matrices or "special case" dirums (see Subsect. 3.5.11). All data input modes are in current use at the various sites. The information becomes part of the permanent record stored with the TRU assay and matrix measurement data.

Modifications and upgrades have been performed at various times since the original algorithm was written in 1982. The developinent and upgrade of hardware and software continue to the present time., ${ }^{622-24}$ The software revisions can be readily accomplished within the FORTRAN software framework of NEUT.

Measured data, as well as all initialization inforniation such as date and time stamp from the internal PC clock/calendar, and final analyzed results are archived on both floppy and internal hard magnetic disks. An on-line hard copy printout of the assay parameters and results is also generated. All background and calibration measurements are routinely recorded and archived in the same fashion as normal assays. Thus a continuous and traceable record of all data is maintained. Most sites, in fact, are maintaining this complete set of data in interactive data bases (e.g., LOTUS 1-2-3 or dBASE III), in which case all single-run assay data occupies one row in a single spreadsheet or data base record. In some cases 10,000 such records exist at a site (e.g., INEL). As such extensive waste drun assay data bases have not been developed previously in the NDA field, much less pui into such readily accessible form, this data-archiving technique is an extremely important development. This greatly facilitates ir ternal consistency checks and comparisons of large numbers of individual drum assay results obtained with different assay techniques.

The RG plutonium (i.e., plutonium containing high ${ }^{240} \mathrm{Pu}$ content) is accommodated within the same PAN algorithm as that used for WG plutonium. The PAN operator is queried before each assay as to whether the drum contains WG plutonium and, if not, what is the correct ${ }^{240} \mathrm{Pu}$ percentage for that waste drum. Once the ${ }^{240} \mathrm{Pu}$ percentage is entered, the algorithm automatically corrects both passive and active assays for the different plutonium isotopics; this includes a specific activity correction to the activity concentration value of nanocuries per gram.

The basic plutonium algorithm cannot, however, directly accommodate ${ }^{238} \mathrm{Pu}$ or HSG plutonium. Those sites assaying HSG plutonium-bearing waste exercise a special algorithm option in their main menus that allows for analysis of the basic passive and active data in terms of HSG plutonium. If selected, this option:

1. Interprets the active assay results in terms of a plutonium isotopic mix consisting of $18 \%{ }^{239} \mathrm{Pu}$ and $82 \%{ }^{238} \mathrm{Pu}$. Because only the ${ }^{239} \mathrm{Pu}$ fraction is fissile, total plutonium mass is obtained by dividing the active assay result by the factor 0.18 .

2. Interprets the passive assay data similarly. Plutonium-238 undergoes spontaneous fission at a rate of $2600 \mathrm{n} \cdot \mathrm{s}^{-1} \cdot \mathrm{g}^{-1}$ (for comparison, the ${ }^{240} \mathrm{Pu}$ rate is $990 \mathrm{n} \cdot \mathrm{s}^{-1} \cdot \mathrm{g}^{-1}$ ). Thus passive coincidence counts can be used to obtain an estimate of ${ }^{238} \mathrm{Pu}$ mass.

3. Uses the system totals passive singles rate to estimate a total alpha particle emission rate assuming oxide as the dominant chemical form. This estimate can then be used to calculate the ${ }^{238} \mathrm{Pu}$ mass.

The SRS possesses most of DOE's ${ }^{238} \mathrm{Pu}$ waste, and all of the three possible ${ }^{238} \mathrm{Pu}$ mass-estimating options described above have been used. Each of the three measurements is most applicable in a given HSG plutonium mass range. For example, option (3) provides the only measurement with sufficient sensitivity to determine the TRU or non-TRU 
(100-nCi/g) cutoff. Both options (1) and (2) have a detection sensitivity down to a few milligrams of ${ }^{238} \mathrm{Pu}$; option (2) is somewhat more sensitive, and option (3) is more applicable for high ${ }^{238} \mathrm{Pu}$ loadings and high passive count rates that commonly accompany the high ${ }^{238} \mathrm{Pu}$ loadings. At present, the SRS is evaluating their ${ }^{238} \mathrm{Pu}$ algorithm.

\subsubsection{Applicability to Contact-Handled Transuranic Wastes}

The PAN systematic matrix correction factors discussed in ref. 6 and Subsect. 3.5.3 and now implemented in all drum-size PAN units enable the quantitative assay of virtually all DOE wastes presently packaged in 208-L drums. At present, these six implemented PAN units have been used to collectively assay about $20,000 \mathrm{CH}-\mathrm{TRU}$ waste drums at the various sites including 2,000 drum assays performed with the mobile drum unit at the NTS and at LLNL.

\subsubsection{Instrument Calibration, Standards Preparation, and Implementation}

Calibration of PAN units includes a through initial calibration after fabrication and routine calibrations using secondary standa:ds. Reference 6 lists the passive and active calibration standards used in all the present PAN units, all of which have origins traceable or referenceable to the National Bureau of Standards. An extensive absolute and matrix standards calibration of each PAN unit was conducted at LANL prior to installation at the various sites. The PAN units were then provided with a set of secondary standards (placed in "Pink Drums" for conspicuous identification) consisting of standard, NBS-referenceable ${ }^{252} \mathrm{Cf}$ passive assay and ${ }^{235} \mathrm{U}$ active assay materials. A baseline reference data set for both passive and active assays was obtained for each PAN unit with these unique Pink Drum standards, and each unit has subsequently performed standard Pink Drum assays prior to each set of PAN waste drum assays.

Figure 6 shows a typical set of these standards measurements performed with the INEL PAN unit and extending for almost a 3-year period. The individual passive and active standards measurements fall well within a $\pm 5 \%$ window; no measurable systematic drift occurred during the 3-year operational history. Reference 6 lists the corresponding Pink Drum measurements for Hanford, the SRS, and the mobile drum unit. All displayed the same basic stability of response.

\subsubsection{Operator Training Requirements and Practices}

PAN units today are highly automated computer-based systems. The instruments are computer-controlled using relatively interactive (i.e., "user-friendly") software. Only trained personnel are allowed to operate the assay equipment. Personnel are qualified according to DOE guidelines. ${ }^{11}$

\subsubsection{Assay Procedures}

The PAN assay systems are comparatively recent additions (i.c., approximately 7 years) to NDA instrumentation; as a consequence, ASTM and ANSI standards have not, as yet, heen developed for PAN assay systems. Active assay techniques have heen used for 


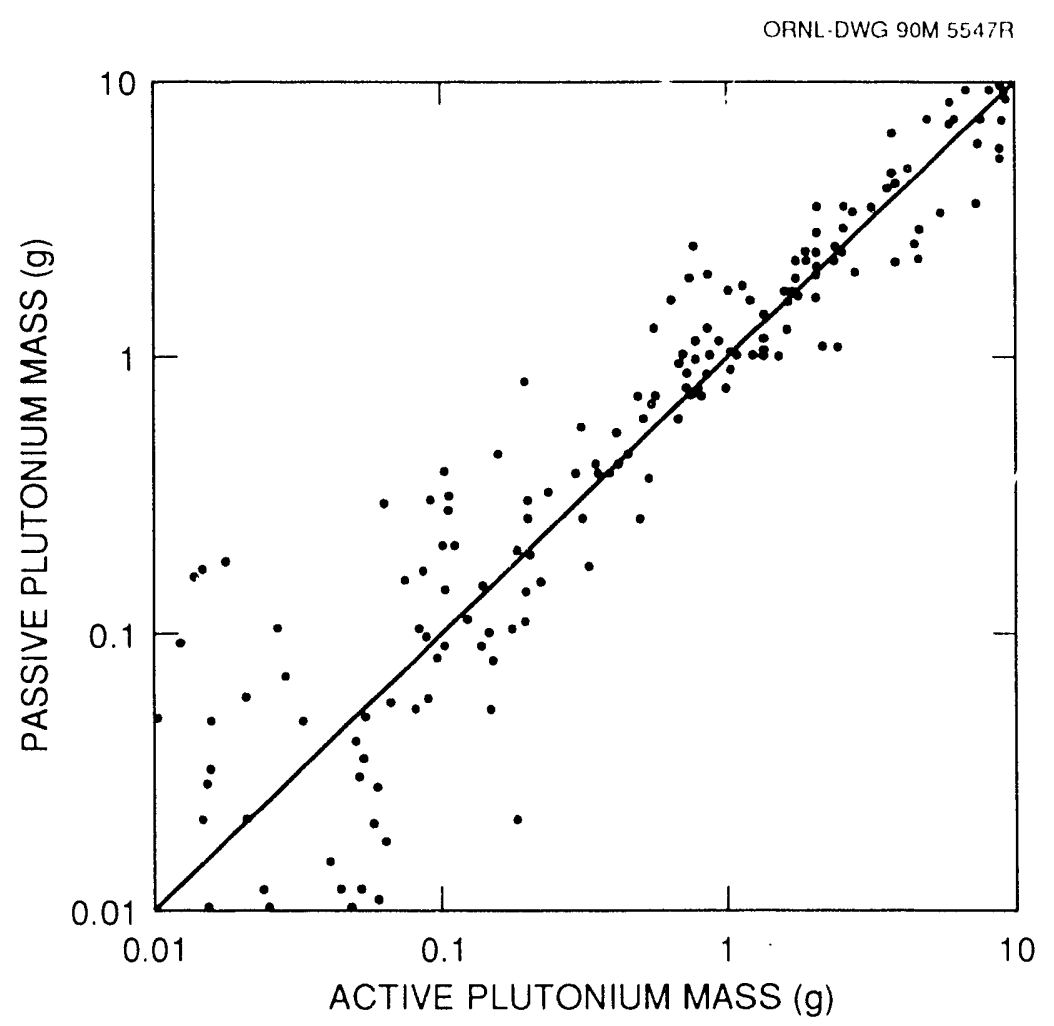

Fig. 6. Comparison of $\mathbf{3 0 0}$ I lanford contact-handled transuranic waste drum assays performed with the passive-active neutron system (passive neutron compared with active neutron). Straight line $(\mathrm{X}=\mathrm{Y}$ ) depicts ideal case where assay techniques shown yield identical assay measurement results.

approximately 18 years, but $14-\mathrm{MeV}$ thermalized neutron assay (i.e., the active portion of PAN) is comparatively recent. Of course, the passive coincidence portion of PAN is similar to the PNCC assay technique; therefore PNCC ASTM, ANSI, and NRC standard practices and guidelines are followed for that portion of the PAN system.

All PAN standard operating procedures instruct operators to acquire a background and a Pink Drum data set before any assays on waste containers are performed. These data sets are checked for consistency; if the results fall outside a $\pm 10 \%$ acceptance window (e.g., $\pm 10 \%$ ), remedial action is taken. The remedial action can include a repetition of the background and/or standards measurements. If the second measurement is successful, general assays can resume. If the problem persists, qualified personnel are contacted to "debug" the system. No CH-TRU waste drum assays can resume until the problem is satisfactorily resolved. If the background or standards measurement is outside the acceptance window, the diagnostic generally assumed is that a hardware problem exists.

The assay procedure for PAN units equipped with the IBM/PC data acquisition system is relatively straightforward. An operator inserts a waste drum into the PAN unit and enters all drum identification information via an interactive dialogue. (PAN assay system softwars, NEUT, prompts the operator for the specific information.) Once NEUT has checked the information for correct format, the assay record and programmable electronics hardware are properly indexed, gates are set, etc. NEUT then sends a message to the operator [via the cathode-ray tube (CRT) screen] that the system is ready to begin an assay. 
At this point, the operator presses one button: the start sequence button on the MA165C neutron generator controller unit. This initiates the PAN active assay. At the conclusion of the active assay, NEUT automatically records all data and initiates the PAN passive assay. At the conclusion of the PAN passive assay, all data are recorded, analyzed, and printed out for immediate inspection. The operator is then informed (via the CRT screen) that the system is ready to perform another assay.

\subsubsection{Assay Precision, Bias, and Limit of Detection}

The PAN assay algorithm contains a calculation of the measurement error ${ }^{7}$ that compounds statistical and estimated systematic uncertainties based on the measured matrix correction factor. For a generally heterogenous matrix and TRU materials distribution, the larger the indicated matrix correction is, the larger the expected assay uncertainty. These values are reported with the actual assay values for both passive and active neutron assays. For many well-characterized waste streams, a typical value for the estimated uncertainty (not including the statistical contribution to the error) is $20 \%$.

When a systematic matrix correction formalism is used, the corresponding systematic uncertainty in the passive assay measurement can be decreased to 5\% or less. This low of an error is valid for dry, combustible, low-hydrogen content waste such as general laboratory waste. The passive assay value uncertainty is calculated in the same manner as that for PNCC with the addition of a term representing the uncertainty in the matrix correstion factor. The algorithm used in the passive coincidence portion of the PAN units calcı lates a composite assay error based on combining all the effects discussed above; this becomes part of the permanent archived assay record.

The active assay value uncertainty estimate includes a systematic bias contribution, a function of the matrix correction factor (AI and MI). For reasonably uniform TRU radionuclide distributions (such as those found in sludges), AI measurements indicate assay uncertainties of $\pm 10 \%$. For nonuniform TRU radionuclide distributions, the uncertainty is a function of the magnitude of the matrix correction factor (i.e., the larger the matrix correction factor, the larger the associated assay uncertainty). ${ }^{6}$ The effects on the assay measurement of concentrated TRU activity in different drum locations have been calculated and plotted as a function of the total matrix correction factor (e.g., a matrix correction factor of approximately 5 yiclds a corresponding uncertainty of $50 \%$ in the assay measurement).

Extensive comparisons have been performed for passive and active neutron assays of the same drum for a great variety of matrix types (c.g., four types of sludges, job-control wastes, combustibles, graphite scarfings, miscellaneous metals, tantalum crucibles, glassware, molten salts, filter media, dirt, and others). Some of these comparisons are shown in the figures of this report and are discussed in refs. 12 and 13). Note that the matrix corrections applied to passive and active assays for a given type of matrix (except where no matrix corrections are necessary) are quite distinct. Thus a very low probability of obtaining agreement by accident exists between active and passive neutron assays for wastes with significant moderator and absorber amounts. If one obtains agreement, both independent PAN assay techniques are considered to yield unbiased assay measurement values. Table 6 summarizes PAN assay biases. 
Table 6. Passive-active neutron assay biases

\begin{tabular}{cc}
\hline Matrix correction factor & $\begin{array}{c}\text { Error } \\
(\%)\end{array}$ \\
\hline $1.0^{a}$ & 20 \\
4.0 & 30 \\
5.0 & 50 \\
\hline
\end{tabular}

${ }^{a} \mathrm{MCF}=1.0$ corresponds to a "no matrix correction" case.

The assay limit of detection for the active neutron portion of the PAN unit can be as low as a few milligrams of ${ }^{239} \mathrm{Pu}$ placed anywhere within a typical $208-\mathrm{L}$ waste drum.

\subsubsection{Passive-Active Neutron Assay Results Comparisons}

Comparisons of PAN assay results with SGS or radiochemical assay methods have been performed. The PAN assays, both passive and active, agree well when compared with SGS and radiochemistry assay results for (1) matrices requiring little or no matrix corrections such as graphite molds and general laboratory wastes and (2) homogeneous matrices (e.g., sludges).

Two papers detail several comparisons of PAN and SGS assay measurements. ${ }^{7,13}$ Reference 7 includes a total data base of some 5000 assays performed at LLNL, Hanford, INEL, LANL, the NTS, and the SRS. The drum assay and matrix correction formalism presented in ref. 6 was extensively evaluated for all types of waste matrices and waste content codes being generated within the DOE complex. Reference 13 encompasses an even larger data base but is confined to INEL PAN assays and comparisons with RFP SGS assays.

Figures $7(a), 7(b)$, and $7(c)$ show a recent PAN SGS comparison performed by LANL personnel using a mobile PAN drum-sized unit. ${ }^{23}$ The data were acquired at LLNL from assays of a set of some 200 208-L, WG plutonium waste drums consisting of general laboratory wastes (e.g., glassware, cellulosics, plastics, etc.) that had been assayed using the LLNL SGS unit. Figures $7(a), 7(b)$, and $7(c)$ show the PAN passive neutron, PAN active neutron, and SGS assay measurements comparisons respectively. A statistical analysis of this data set indicates systematic agreement between both PAN neutron data sets and the SGS assay results at the 5\% level (95\% confidence level). Figure 6 shows a plot of similar waste stream assays performed with the Hanford PAN system comparing passive and active neutron assay values for a set of 400 waste drums.

Figures $8(a)$ and $8(b)$ show a set of over 200 "graphite molds" matrix waste drums (RG plutonium) assayed with the PAN unit at INEL and also with an SGS unit located at the RFP. A statistical analysis of this data set indicates systematic agreement of all three independent assay methods to within $10 \%$ on the average at the $95 \%$ confidence level.

Quantitative comparisons between radiochemical plutonium (WG) and ${ }^{241} \mathrm{Am}$ determinations and active PAN have been performed at INEL's Solid Waste Examination Pilot Plant (SWEPP). ${ }^{7}$ These comparison studies of approximately 1300 drums of RFP aqueous sludges comprise more than 100 individual sludge batches. These sludges contain low plutonium and relatively high americium concentrations. Figure 9 shows the results of these comparisons.

The batch-average drum plutonium assay as determined at RFP was compared with the same quantity as that measured with the INEL PAN unit. The indicated straight line 


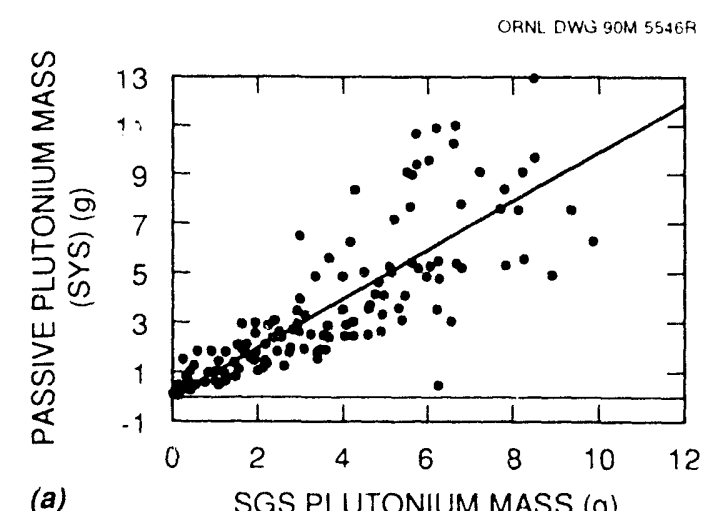

(a) SGS PLUTONIUM MASS $(\mathrm{g})$
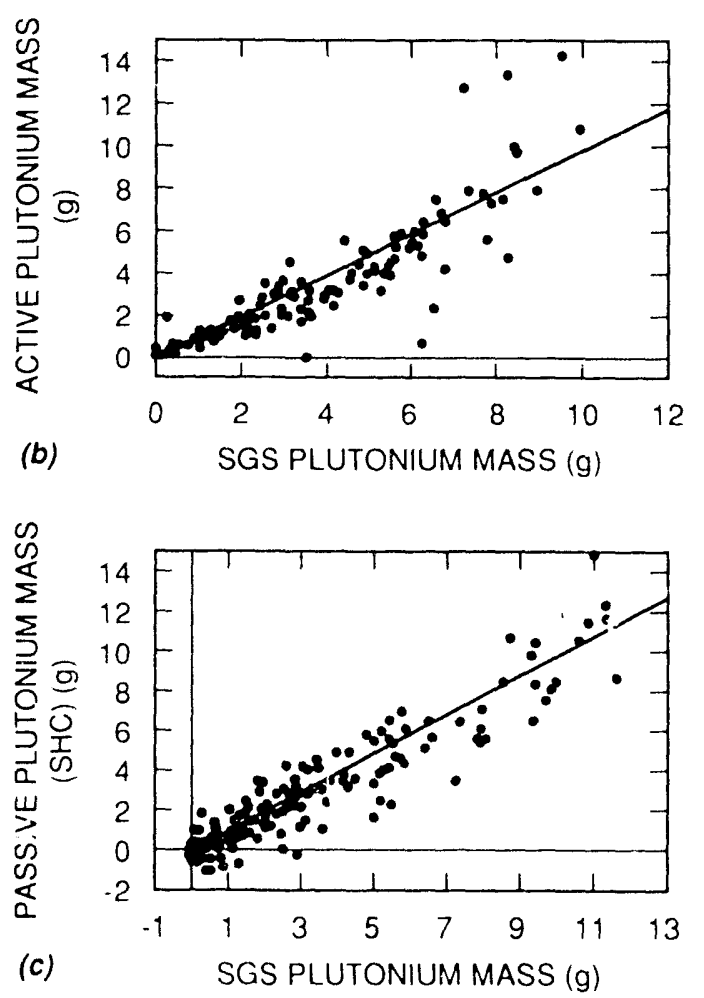

Fig. 7. Comparison assay data sets of 200 lawrence Livermore National Laboratory contact-handled transuranic waste drums; waste matrix is nonsegregated general laboratory waste: (a) passive neutron (PAN) compared with segmented gamma scanning (SGS), (b) active ncutron (PAN) compared with SGS, and (c) comparison of the two inch prenent $\mathrm{PAN}$ passive $\mathrm{D}$ :utron assay systems. Straight line $(\mathrm{X}=\mathrm{Y})$ depicts ideal case where assay techniques shown yield identical assay mansurement results.

shows the relationship RFP plutonium mass $=$ PAN plutonium mass. A statistical analysis of thi', same data indicates a best straight-line fit relationship of

RFP plutonium mass $=-0.0 \leftarrow+0.85^{*} \mathrm{PAN}$ plutonium mass 

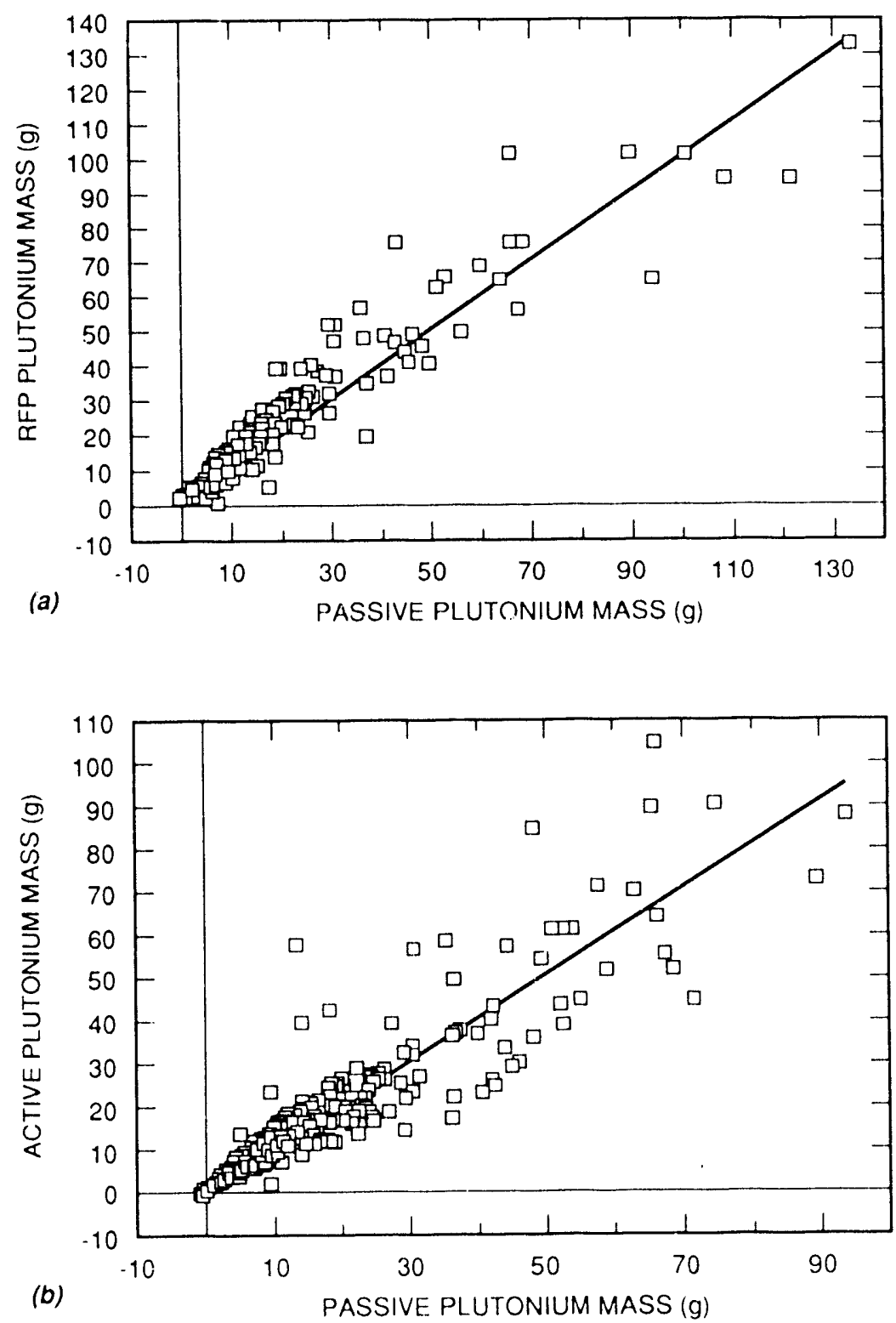

Fig. 8. Assay comparisons of a set of over 200 Rocky Fats Plant (RFP) contact-handled transuranic waste drums (graphite molds matrix) showing RFP segmented gamma scanning system assays compared with (a) PAN unit passive neutron assays and $(b)$ Idaho National linginecring Laboratory $P A N$ active neutron and passive neutron comparisons. Straight lines $(X=Y)$ depict ideal case where assay techniques shown yield identical assay measurement results.

the correlation factor is 0.51 . The calculated correlation factor indicates that $51 \%$ of the variance does fit a straight line. The 0.85 constant indicates an approximately $15 \%$ average measurement bias between the two assay techniques.

The individual PAN systematic measurement uncc, tainty (discussed in detail in ref. 6) for a typical sludge drum measurement is approximately $10 \%$ on the average primarily because of possible systematic uncertaintics in the matrix concetion formalism. That uncertainty estimate is based on the observed standard deviation found for mockup sludge drum calibrations. PAN systems are able to measure the total uncorrelated reutrons but 
cannot measure the individual contributions from mixed, uncorrelated sources of neutrons [e.g., $(\alpha, n)$ reactions due to ${ }^{244} \mathrm{Cm}$ and ${ }^{241} \mathrm{Am}$ ]. The contributions from ${ }^{241} \mathrm{Am}$, for example, can be calculated (obtained from passive single neutron rate) if no other $(\alpha, n)$ sources are present in the waste.

The two assay measurement techniques appear to agree within probable systematic uncertainties associated with each technique (assuming $a \pm 10 \%$ systematic uncertainty for both techniques). Other similar individual sludge drum NDA comparisons (i.e., passive and active PAN neutron assays of high-plutonium, low-americium activity sludge drums ${ }^{7}$ ) verify the basic PAN matrix corrections at the $\pm 10 \%$ level. Reference 13 details additional such comparisons for a great variety of matrix types including heterogeneous matrices and highly neutron-absorbing matrices. In all cases the PAN assays are highly correlated with SGS assays and with each other. Comparison studies indicate a slightly better agreement between PAN and radiochemistry assay methods than the 10 to $15 \%$ discussed above. ${ }^{13}$

\subsubsection{Decision-Trec Analysis}

Two independent assay values, a "passive" mass and an "active" mass, are obtained with each PAN assay. A "decision-tree analysis" is performed within the assay algorithm by an analytical evaluation of assay conditions. The default decision is to choose the active assay for low plutonium mass $(<10 \mathrm{~g})$ and the passive assay for high $(\geq 10 \mathrm{~g})$ plutonium mass. INEL has modified the algorithm to change the decision value to $40 \mathrm{~g}$.

Content-code-specific decision-tree algorithm options are developed by a site based on an evaluation by the NDA data reviewer or expert of the individual site's waste content codes. When specific content code or matrix information is available that indicates, for example, that passive assay results are more reliable than active assay results for that content code, then the algorithm selects the passive assay results when that content code is entered via the PAN operating software NEUT. Similar overrides involve the statistical accuracy of a measurement. For example, if the passive measurement has a large error associated with it, then the active measurement is selected.

The default PAN assay algorithm is known to underestimate the absorption correction factor for various waste streams (e.g., tantalum crucibles). When the tantalum crucible example is considered, this phenomenon is due to neutron tunneling effects caused by the stacked arrangement of the crucibles. A correction factor based on the RFP SGS assay values is used to adjust the PAN assay values.

A similar method is used at INEL to modify the MI obtained during the assay of sludge drums. For lower plutonium-loading waste sludge drums, an average MI is used in the assay value calculations. The average MI value was obtained from previous assays of the same waste stream containing higher plutonium loadings and, thus, higher count rates and improved counting statistics.

One decision-tree analysis used by Hanford is based on experimental results indicating that fissile self-absorption effects in several of their content codes were small for plutonium mass loadings of $10 \mathrm{~g}$ or less but increasingly probable for successively higher plutonium mass loadings. It also took into account the experimental fact that plutonium loadings in excess of $10 \mathrm{~g}$ led to statistically more precise passive assay measurements. Of course, the exact "cross-over" point between using the PAN active or passive assay measurement depends on several experimental factors such as waste form, $(\alpha, n)$ source strength, isotopics, etc. 


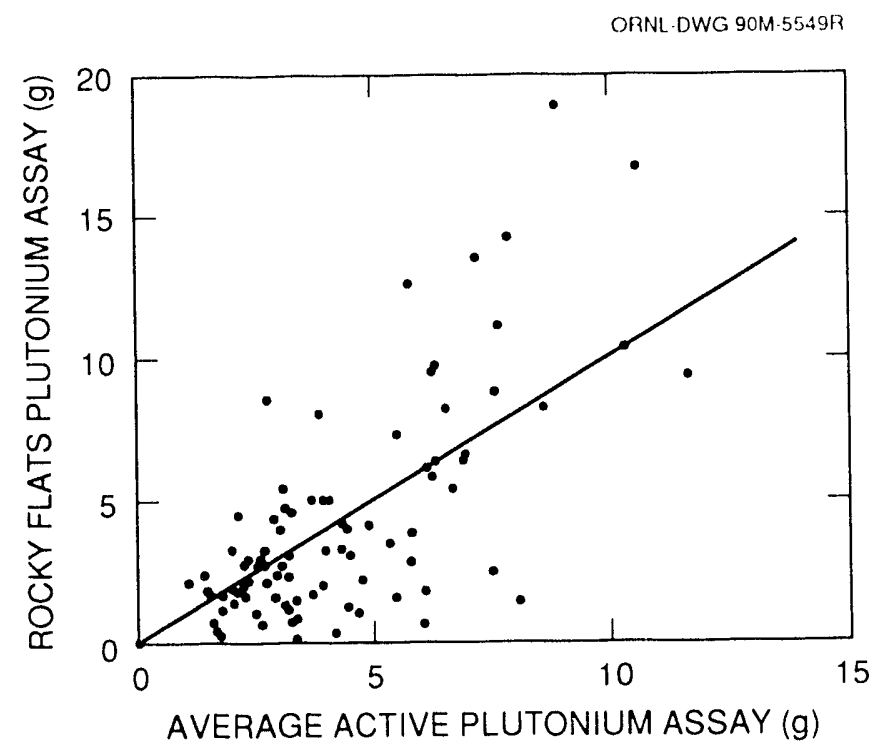

Fig. 9. Batch ayerage plutonium assays of $\mathbf{1 3 0 0}$ sludge drums performed at the Rocky Flats Plant compared with passive-active neutron assays of the same drums performed at Idaho National Engincering Laboratory. Straight line is a linear least squares fit to data.

INEL has modified their PAN decision-tree analysis to reflect the phenomenon that sufficiently strong $(\alpha, \mathrm{n})$ sources cause experimental measurement problems for the PAN passive assay measurement rendering it biased high. If the passive assay statistical precision (i.e., error bar) exceeds $40 \mathrm{~g}$ of plutonium, then the decision-tree analysis selects the selfabsorption corrected active assay value. This decision-tree also reflects the development of a fissile self-absorption model that is applied to all PAN active assays. This model is purely empirical and assumes that the probability of fissile self-absorption is a monotonically increasing function of the total fissile loading in a waste drum. The function is determined from evaluations of large sets of actual $\mathrm{CH}$-TRU waste drum assays employing PAN active and passive neutron and SGS measurements. ${ }^{6}$ The derived functions, however, produce large error bars at the higher fissile mass values. In the "near 200-g plutonium" regime, for example, the self-absorption corrected active assays may have relative uncertainties of $40 \%$.

A decision-tree analysis may also be performed by the site NDA expert when specialcase waste drums are encountered. The various factors that determine what is a "special case" drum include nominal assay values for $\mathrm{CH}$-TRU waste drums near or in excess of the 200 -g criticality limit and a lack of tag isotopics information (e.g., ${ }^{240} \mathrm{Pu}$ content). Both of these situations preclude proper software interpretation of PAN assay measurement data.

Approximately one out of 500 RFP CH-TRU waste drums assayed with the INEL PAN system are assigned an assay value near or in excess of the $200-\mathrm{g}$ criticality limit. Typically, these drums contain very high $(\alpha, n)$ radioisotopic sources that, because of the high numbers of neutrons present, result in poor passive PAN coincidence measurements. The large numbers of neutrons (i.e., approximately $10^{4}$ neutrons per second or greater) decrease the signal-to-noise ratio to below acceptable limits. Content codes 409 and 411 display this characteristic and also contain "lumps" of plutonium that invalidate the active neutron assay. A panel of three or four INEL experts examines and compares all assay and RTR information available including a critical evaluation of the "tag" assay values. After a consensus of the expert panel is achieved, a suitable resolution is proposed, and 
the appropriate action is taken. This action may include acceptance of a tag value of less than $200 \mathrm{~g}$, or the waste drum is returned to the waste generator for repackaging. Both of these actions have occurred.

Hanford waste drum tag values obtained by using an SGS and the certification or check of the SGS assays with a PAN unit occasionally indicate assay values near or in excess of the $200-\mathrm{g}$ criticality limit. The approach used at Hanford is basically the same one employed at INEL, but a two-expert panel is used to evaluate the available data. The return-to-generator option is used frequently with drums having assay values near the 200-g limit.

Invalid or unavailable isotopics information resulted in very high PAN passive coincidence assay measurement values when a small set of Pacific Northwest Laboratory waste drums were assayed at Hanford using a PAN unit. These drums contained ${ }^{244} \mathrm{Cm}$, but this isotope was not originally listed on the accompanying data sheets. Many of the assay values were well in excess of the nominal 200-g limit. Experts resolved the problem through direct dialogues with the waste generator who, subsequently, agreed to provide the proper isotopic information that would then allow these drums to be properly assayed. 


\section{FISSILE MATERIAL CONTENT AND DECAY HEAT VALUE CALCULATIONS}

The fissile or fissionable isotope content for CH-TRU waste containers is expressed in terms of ${ }^{239} \mathrm{Pu}$ fissile gram equivalents defined by $\mathrm{ANSI}^{25}$ The standard lists the maximum subcritical mass limits for fissile and nonfissile actinide nuclides $\left({ }^{233} U\right.$ and ${ }^{235} U$ are considered equivalent to ${ }^{239} \mathrm{Pu}$ ). The fissile material (e.g., ${ }^{239} \mathrm{Pu},{ }^{235} \mathrm{U}$, etc.) or fissionable content of a CH-TRU waste container may be obtained by using any of the previously described NDA techniques. However, except for PAN and SGS assay systems, to obtain a fissile material estimate, the isotopics of the TRU isotopes contained in the waste form must be known. PAN and SGS assay techniques measure directly the content of the fissile material: PAN by the detection of induced fission neutrons emitted by the fissile material (i.e., active portion of the PAN assay) and SGS by the detection of emitted gamma rays (e.g., for ${ }^{239} \mathrm{Pu}, 414-\mathrm{keV}$ gamma and for ${ }^{235} \mathrm{U}, 185-\mathrm{keV}$ gamma). A more detailed discussion of the PAN and SGS assay techniques is given in Subsects. 3.5 and 3.2 respectively. Reference 26 describes the requirements for fissile material content (i.e., nuclear criticality safety) for CH-TRU waste containers destined for shipment to the Waste Isolation Pilot Plant (WIPP).

The PNCC assay method detects the coincident neutrons emitted by the evennumbered TRU isotopes (c.g., ${ }^{240} \mathrm{Pu}$ and ${ }^{244} \mathrm{Cm}$ ). (See Subsect. 3.4 for a detailed discussion of the PNCC assay technique.) Once the coincident neutron (spontaneous fission) emitters have been quantified and the proper correction factors have been applied (e.g., system multiplication, system dead-time, etc.), one can calculate the fissile material content by applying the known isotopic ratios. For example, if it was determined that a WG plutonium-bearing waste container contained $5 \mathrm{~g}$ of ${ }^{240} \mathrm{Pu}$, one simply divides the $5-\mathrm{g}$ value by the factor $(0.94 / 0.06)$, which is the typical WG $\mathrm{Pu}$ isotopic ratio of ${ }^{239} \mathrm{Pu}$ to ${ }^{240} \mathrm{Pu}$, to yield $78 \mathrm{~g}$ of ${ }^{239} \mathrm{Pu}$ fissile mass content. After the mass of each TRU isotope present has been determined, the decay heat can be calculated by multiplying the mass of each isotope by the decay heat per gram of the isotope. For the general case of alpha and beta decay, the decay heat per gram csin be calculated by using Eq. 10 in ref. 9 (see refs. 9 and 27).

The original PAN system algorithm used a very conservative means to estimate a waste drum's decay heat. First, it was assumed that only the drum's alpha particle inventory was responsible for the waste drum's decay heating. Secondly, the conservative assumption was made that all neutrons detected were produced by $(\alpha, n)$ reactions within the drum's waste matrix. In the original algorithm this assumption led to the value of $98,000,000 \mathrm{McV}$ of alpha decay heat energy being associated with each neutron emitted. This estimate is conservative for two reasons:

1. In all cases of WG plutonium, a fraction of the neutrons detected are produced by ${ }^{240} \mathrm{U}$ or other spontaneous fission reactions, which have a much lower decay-heat-perneutron factor. Typically each spontaneous fission neutron is associated with approximately $100 \mathrm{MeV}$ of decay heat energy.

2. In many waste packages the actual $(\alpha, n)$ production factor is higher than the conservative value $\left(2 \mathrm{n} \cdot \mathrm{s}^{-1} \cdot \mathrm{mCi}-\alpha\right)$ used in the PAN algorithm. Production factors as high as $14 \mathrm{n} \cdot \mathrm{s}^{-1} \cdot \mathrm{mCi}-\alpha$ were observed for RFP CH-TRU waste drums when assayed with the INEL PAN system. ${ }^{26}$ For the various fluoride, mangnesium, aluminum salt, and typical sludge matrices, values as high as $100 \mathrm{n} \cdot \mathrm{s}^{-1} \cdot \mathrm{mCi}-\alpha$ are observed..$^{28}$ 
To obtain more realistic estimates of the decay heat value for sludge wastes and those containing fluorides, INEL has used an experimentally determined $(\alpha, \mathrm{n})$ production factor. For example, an experimentally determined production factor is being used for RFP aqueous sludges. ${ }^{28}$ This derived production factor has been incorporated into the PAN assay algorithm.

Hanford and SRS use an $(\alpha, \mathrm{n})$ production factor based on given plutonium isotopics contained in the waste drum. The modified PAN assay algorithm assumes that the entire 241 mass (i.e., sum of ${ }^{241} \mathrm{Pu}$ and ${ }^{241} \mathrm{Am}$ ) is in the form of ${ }^{241} \mathrm{Am}$. This assumption is very conservative since ${ }^{241} \mathrm{Am}$ produces approximately 35 times the decay heating associated with ${ }^{241} \mathrm{Pu}$.

ORNL uses a PAN decay heat calculation algorithm based on the subtraction of the spontaneous fission neutron portion (passive neutron coincidence) from the observed total neutron count rate. Error bars associated with the decay heat calculation propagate in the same fashion as that described for PAN plutonium mass calculation (see Subsect. 3.5.9).

The administrative classification of $200 \mathrm{mrem} / \mathrm{h}$ for container surface dose rate imposed for CH-TRU. waste automatically limits the decay heat contributions from betaand gamma-emitting radioisotopes. To calculate the fission product inventories required to generate a surface dose rate of $200 \mathrm{mrem} / \mathrm{h}$, one can assume that the total external surface dose rate is produced by fission products (i.e., the beta and gamma emitters). Any TRU radioisotopes present are conservativ !y assumed not to contribute to the observed external dose rate. One also assumes that the short-lived fission products have decayed sufficiently to be of no concern. This is a conservative assumption since most waste drums are more than 1 year old. Consequently, only a small number of "pure" beta emitters would then be present (e.g., ${ }^{90} \mathrm{Sr}$ ). The remaining predominant radioisotopes producing the heat-generating radiation other than ${ }^{90} \mathrm{Sr}$ would then be ${ }^{137} \mathrm{Cs}$ and ${ }^{60} \mathrm{Co}$.

Consider a $\mathrm{CH}-\mathrm{TRU}$ waste drum containing $100 \mathrm{~kg}$ of medium atomic number wastes. Assume that the maximum allowable container external dose rate of $200 \mathrm{mrem} / \mathrm{h}$ is involved and that this rate is attributable solely to beta and gamma emitters (again, a conservative assumption). Also, assume that the radioisotope inventory of this waste drum is a mixture of the dominant long-lived fission product species ${ }^{90} \mathrm{Sr}$ and ${ }^{137} \mathrm{Cs}$. For longterm decay $6.5 \%{ }^{137} \mathrm{Cs}$ and $2.2 \%{ }^{90} \mathrm{Sr}$ are produced by reactor fissions. ${ }^{29}$ This fission product mixture produces a decay heating of $0.91 \mathrm{MeV}: 50 \%$ derived from beta emission and $50 \%$ derived from gamma-ray emission. ${ }^{30}$

If one also makes the couservative assumption that (1) only the ${ }^{137} \mathrm{Cs} 0.67 \mathrm{MeV}$ gamma ray exits the waste drum, (2) the ${ }^{137} \mathrm{Cs}$ is located in the center of the waste drum, and (3) the mass attenuation factor is very conservative (i.e., $0.74 \mathrm{~cm}^{2} / \mathrm{g}$ ), one can calculate the curies required to produce a container external dose rate of $200 \mathrm{mrem} / \mathrm{h}$. These assumptions and calculations yicld an estimate of $0.25 \mathrm{Ci}$ of ${ }^{137} \mathrm{Cs}$ present in the example waste drum. Using the isotopic ratio discussed earlier, one calculates a beta and gamma decay heating of $0.001 \mathrm{~W}$. This decay heating value is equivalent to that produced by the alpha emissions of 0.4-g WG plutonium.

Detailed gamma-ray spectral studies of ORNL and RFP CH-TRU waste drums indicate that the detected gamma rays were attributable to TRU isotopes and not to fission products. ${ }^{20,28,31}$ Consequently, from the calculations above and the small quantities of observed fission products, the contributions to the waste drum decay heat from beta and gamma emitters are negligible. 


\section{NEW NONDESTRUCTIVE ASSAY DEVELOPMENTS}

In keeping with DOE's general policy of upgrading NDA hardware, software, and procedures, DOE continues to support a vigorous NDA development program, specifically TRU waste assay-related instrumentation. One recent example of this development is a significantly improved digital processing unit (i.e., upgraded shift register) for use with PNCC units that greatly reduces basic dead-time limitations associated with older PNCC units and lowers processing errors. These newer processors are now either installed or in the process of being installed in all DOE facilities using PNCC assay techniques.

Another development nearing the implementation phase in support of the PAN assay method is "neutron imaging" of 208-L waste drums. ${ }^{32}$ With little change in the basic PAN hardware, 208-L waste drum assay data may be acquired in a fashion that allows it to be processed with existing imaging software similar to that used in medical computer-assisted tomography scans. Neutron imaging has already been demonstrated using an upgraded mobile PAN unit. ${ }^{32}$ Improved matrix and self-absorption corrections to the acquired assay data will then be possible using the neutron imaging technique. More precise

determination of the TRU radionuclide distribution should result in the minimization of assay biases since it is known that incomplete matrix and self-absorption corrections are a major source of assay uncertainties.

PAN box assay systems have been used in the DOE complex for several years. The earlier versions including assay campaigns at the NTS and the RFP are discussed in several of the references. ${ }^{7,22,23}$ Recently, some improvements in the box PAN systems were made and implemented at some of the sites. The new box assay unit at INEL and the mobile system box assay unit are examples of this implemented PAN technology. The improvements have been applied in four areas:

1. improved matrix corrections made possible by development and deployment of a "moving" shielded flux monitor that samples the emergent interrogating flux along the entire length of a box;

2. improved detection uniformity throughout the box volume made possible by an improved detector layout;

3. smaller matrix inhomogeneity assay uncertainties achieved by implementation of a source location algorithm, which effects matrix corrections correlated with the location of the TRU radionuclide content; and

4. in:plementation of IBM/PC data acquisition/controller hardware and software.

Improvement (1) is similar to the shielded flux monitor (described in Subsect. 3.5) that is used in the drum-size PAN systems. These new developments are being implemented simultaneously with the institution of a new standard waste box designed for shipment of $\mathrm{CH}$-TRU waste in the TRUPACT II. 


\section{QUALITY ASSURANCE AND QUALITY CONTROL PRACTICES}

QA and QC are important functions at all DOE facilities, especially in special nuclear materials accounting areas. The eighteen elements of NQA-1 are being implemented throughout the DOE. ${ }^{11}$ TRU waste assay QA and QC practices adhere to the guidelines established in NQA-1. Some of these practices have been discussed previously in relationship to other subjects. A brief listing of some of these QA/QC practices in common use to assay newly generated and stored $\mathrm{CH}$-TRU waste throughout the DOE complex are:

1. Expert NDA personnel checks of NDA records before assay values assigned to the waste package (NQA-1 Elements 1 . Organization and 10. Inspection). The functions of these site NDA reviewers or experts have been discussed previously in Subsects. 3.2, 3.4 , and 3.5 ).

2. Use of assay standards before and after waste assays (NQA-1 Element 12. Control of Measuring and Test Equipment). Detailed discussions of instrument calibration and calibrations standards preparation and implementation have been discussed in detail for each assay method in Subsects. 3.2.1.3, 3.4.3, and 3.5.6).

3. Achievement of automatic electronic system gain stabilization. (NQA-1 Element 3. Design Control). For each assay method, manufacturer's system instructions and site operating procedures suggest to the assay system operators the correct settings for proper system gain and stabilization.

4. Implementation of automatic software flagging and tagging for special-case waste containers (NQA-1 Element 5. Instructions, Procedures, and Drawings). For example, less than $0.5 \%$ transmission segments are flagged for SGS assay measurements, and special-case waste matrices are flagged by the computer algorithm in PAN assay measurements.

5. Identification by administrative tagging of failed segment assays as "LOWER LIMITS" (NQA-1 Element 15. Control of Nonconforming Items). This procedure is performed for those SGS waste drums that qualify.

6. Archiving of original segment assay and calibration data for future reference (NQA-1 Elements 6. Document Control and 17. Quality Assurance Records). PAN assay algorithm automatically archives all calibration data acquired (sce Subsect. 3.5.6).

7. Preparation of detailed data sheets that accompany each drum through all NDA, RTR, etc. stations. Some sites (e.g., INEL) use automated, computerized data sheets and bar codes (NQA-1 Element 9. Control of Processes).

8. Verification of most sites' SGS assays by one or two other independent NDA measurements (e.g., at a central certification facility). For example, RFP SGS assays are verified by the INEL PAN passive and active assay measurements (NQA-1 Elements 9. Control of Processes and 18. Audits).

9. Return of nonconforming drums for repackaging (NQA-1 Element 15. Control of Nonconforming Items). When a drum is found to contain nonconforming items after RTR inspection or to contain, for example, greater than the acceptable nuclear criticality limit, it is returned to the waste generator for repackaging.

10. Use of RTR inspections in appraisal of NDA "special-case" waste containers to aid in the evaluation of matrix problems (NQA-1 Element 16. Corrective Action). For example, special-case waste drums (e.g., INEL tantalum crucible content code) are flagged by the PAN assay algorithm through previous evaluation and identification of 
the content code by the site NDA reviewer (expert). See Subsect. 3.5.11 for a more detailed discussion of the special-case waste drums.

11. Routine use of RTR inspections to verify or to evaluate waste form or content code of all waste drums (NQA-1 Element 8. Identification and Cortrol of Items). RTR inspections are used to confirm the proper identification of waste content codes.

12. Upgrading of NDA hardware, software, and procedures as a general practice (when fiscally possible) (NQA-1 Elements 2. Quality Assurance Program and 3. Design Control). See Sect. 5 for a discussion of new NDA developments.

It is DOE policy to conduct periodic audits of all WIPP certification activities at each site. ${ }^{33}$ The audit teams consist of technical NDA [and nondestructive evaluation (NDE)] personnel, together with administrative personnel, knowledgeable in several of the NDA technologies discussed in Sect. 3. These audits are designed to provide independent monitoring and evaluation of each site's NDA and NDE activities on a regular basis and to foster compliance with certification plans. These in-depth evaluations take place on-site, and a detailed audit team report (including recommendations for improvements in areas judged deficient) follows each such audit. In addition, each site conducts independent internal audits on at least an annual basis that cover the same overall procedures as those performed in the DOE external audits. The effect of these audits is to provide considerable independent oversight of each DOE site's NDA and NDE operations as overlays to each site's routine operation activities (described in Sect. 7). 


\section{SITE-SPECIFIC NONDESTRUCTIVE ASSAY USAGE}

\subsection{OVERVIEW}

As can be seen from a review of Table 1, most sites use more than one assay method to certify their CH-TRU wastes. This process allows both comparisons between assay methods and additional verification of assay results. Also, through this process "specialcase" wastes are identified for further evaluation; this may include assay by other assay methods or return to the generator for repackaging. The following subsections provide in some detail the assay technology used at each DOE site that generates and/or stores $\mathrm{CH}$-TRU wastes.

\subsection{ARGONNE NATIONAL LABORATORY}

A small number (i.e., $<10$ ) of $\mathrm{CH}-\mathrm{TRU}$ waste drums are produced annually at ANL-E. These drums are derived from activities that result in two distinct waste streams: process liquid wastes and glove box residue solids. The liquid wastes are sampled in aliquots prior to adsorbing them onto vermiculite for final drummed packaging. The aliquot liquid samples are assayed using standard alpha spectrometry techniques (Subsect. 2.5); the procedures for this adhere to standard ANSI and ASTM guidelines. Individual waste drum TRU assay values (primarily plutonium) are calculated based on the aliquot sample alpha spectrometric values and the adsorbed waste volume in each drum.

The glove box solid wastes are assayed using a commercial SGS assay unit (see Subsect. 2.4 for a detailed SGS technical discussion including standards and assay procedure). Traceable, certified standards are used prior to and immediately after each NDA measurement session. Calibrations are performed in matrix and geometric configurations simulating the actual waste distributions in the 208-L waste drums. At present, all ANL-E waste drums are shipped to INEL for interim storage. Some assay elata comparisons with the SWEPP PAN unit will become available during the assay of the ANL-E drum inventory.

\subsection{IDAHO NATIONAL ENGINEERING LABORATORY}

The personnel at the SWEPP facility, the INEL central certification facility, certify all newly generated and stored CH-TRU wastes intended for shipment from the INEL to the WIPP. The NDA systems presently in use are two PAN units, one sized for 208-L drums and the other for crates (maximum crate dimensions of $1.37 \times 1.37 \times$ $2.13 \mathrm{~m}$ ). The drum unit has been in continuous operation since September 1984, and more than 10,000 CH-TRU waste drums have been assayed. As mentioned in Sect. 3, LANL has developed standard operating procedures, calibration protocol, and a computer-based algorithm matrix correction formalism for the PAN units. These developments are documented in ref. 6 . The formalisms discussed in detail in ref. 6 are used in the SWEPP drum unit in the form of the IBM/AT-based operating system algorithm called NEUT. This program, together with the digital electronics associated with the IBM/AT-based data acquisition system, are discussed in more detail in ref. 34 .

The PAN operating software systems have been written for the IBM/AT to provide automatic data base archiving on both internal hard disk and floppy disks. All 
measurement data (i.e., waste container identification code, weight, content code, date and time of data acquisition, date and time of all calibration measurements and detector backgrounds, calibration and background data measurements) are also archived. Analyzed data results (including key intermediate analysis quantities useful in tracing systematic behavior of common content code drums) are recorded and archived. Although the assays are analyzed by the PAN computer algorithm, this archival data is maintained on a permanent basis for QA document control purposes and to make possible future updated algorithm analyses of the results.

SWEPP operators are given extensive training and must pass a series of written and/or oral examinations designed to certify their understanding of the measurement principles and characteristics of the hardware and operating procedures. A detailed set of operating procedures (current version is SWEPP-036-88) is maintained by the SWEPP operational managers.

A set of combined passive-active neutron assay standards (standard sources include

${ }^{252} \mathrm{Cf}$ and depleted ${ }^{238} \mathrm{U}$ ) including background measurement is measured each day that assay measurements are obtained. Those data are archived on hard and floppy disks. A hard copy is provided for immediate consideration by the operators. Part of the standard operating procedures consist of the requirement that background and standards assay measurements fall within a standard operations window of $\pm 10 \%$ before actual waste drum assay measurements begin. Figure 10 shows the results of those daily calibration measurements spanning a 3-year operational period, referenced to the original Los Alamos calibrations, that were performed in June 1984. Because the passive and active assay calibrations are obtained independently, each NDA PAN calibration is shown. Note that this assay equipment has achieved an excellent operations history: over 10,000 drums have been assayed to date.

\subsection{LAWRENCE LIVERMORE NATIONAL LABORATORY}

LLNL utilizes the concept of multiple NDA measurements for their CH-TRU wastes (see Table 1). All drummed wastes are assayed using an SGS system and, subsequently, a PAN mobile unit. Figures $7(a)$ and $7(b)$ show a comparison of the three independent assay methods used to inspect 200 LLNL drums. The self-consistency among the three independent methods is clearly demonstrated. The LLNL SGS unit conforms to the guidelines given in the previously referenced ASTM and ANSI standards (i.e., all waste assays are preceded with appropriate calibration standards measurements).

\subsection{LOS ALAMOS NATIONAL LABORATORY}

LANL has three distinct, major waste streams: process sludges, Technical Area (TA)-55 "job-control" wastes, and interim stored wastes. Several waste categories are produced within the three waste streams; these are recorded on each waste drum's specification sheet. Because the three waste streams are physically separated by a significant distance (i.e., several miles), each has its own complement of NDA equipment. The process sludge wastes are either dried or cemented before packaging into 208-L drums. A radiochemistry (i.e., alpha spectrometry) sampling is obtained similar to that discussed in Sect. 2. LANL's procedures are adequate to ensure homogeneous mixtures during sampling of the sludge and subsequent drum filling. However, independent NDA measurements of a sampling of these sludge drums is planned on installation and 
ORNL-DWG 90M-5545R
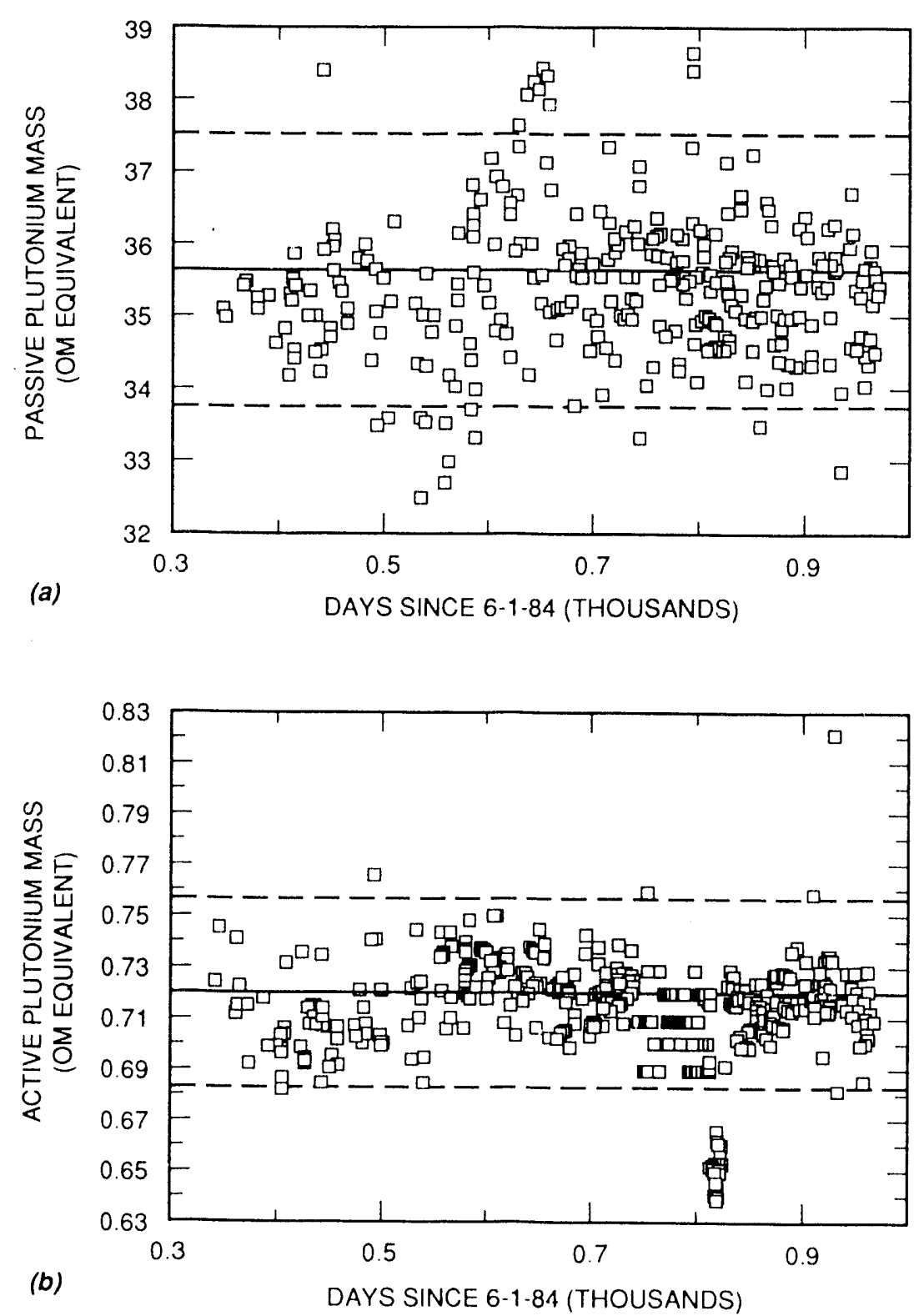

Fig. 10. Idaho National Engincering Laboratory standards measurements (Pink Drum) performed over a 3-ycar period: $(a)$ passive standard and $(b)$ active standard. Dashed lines indicate a $\pm 5 \%$ measurement error band about expected standards assay values.

implementation of a PAN assay unit for area HSE-7. These verification measurements will help to validate the radiochemistry assay results and the sampling and drum-filling homogeneity assumptions.

TA-55 job-control wastes are well segregated and characterized wastes that arise as a result of the TA-55 WG plutonium operations. Many of the very first NDA instrumentation developments were first implemented in TA-55 including the first 208-L drum-size NDA system, a PNCC unit installed more than 10 years ago. The Multienergy Gamma Assay System (MEGAS), an early version of the SGS system, was also first implemented at TA-55. The MEGAS is still uscd at TA-55 primarily as a screening 
instrument for low-density wastes packaged in small cardboard boxes. An interim storage waste facility located in TA-51 will be serviced with a second-generation PAN unit.

\subsection{EG\&G, INC., MOUND FACILITY}

Mound uses two well-established NDA technologies for the small volume of TRU wastes generated at that facility: SGS and calorimetry. Mound has used the calorimetric method to verify its SGS assay measurements. Almost all the Mound CH-TRU waste is generated during its HSG plutonium operations; this waste type is readily amenable to assay by both methods employed. All of Mound's CH-TRU wastes generated prior to 1988 will also be assayed in the SWEPP INEL PAN unit. Consequently, all wastes generated prior to 1988 will be assayed by three independent NDA measurements.

The PAN assay methodology for HSG plutonium wastes has been developed, tested, and used for routine heat source waste assays at ORNL and the SRS. The total heat source plutonium mass can be estimated by three independent methods using the following PAN assay methodology:

1. from the measured ${ }^{238} \mathrm{Pu}$ spontaneous neutron fission rate (i.e., passive neutron coincidence rate),

2. from the measured passive singles neutron rate based on ${ }^{238} \mathrm{Pu}(\alpha, \mathrm{n})$ reactions with typical matrix materials, and

3. from the measured active neutron assay ${ }^{239} \mathrm{Pu}$ mass using heat source isotopics (where ${ }^{239} \mathrm{Pu}$ averages about $18 \%$ of the total heat source plutonium mass by weight).

The present second-generation PAN units contain the HSG plutonium (i.e., ${ }^{238} \mathrm{Pu}$ as the dominant radioisotope) assay algorithm, which can be accessed during the setup phase of the NEUT system operating program menu. The mobile PAN drum unit is a secondgeneration unit and is available upon request to perform on-site independent quality $\mathrm{QA} / \mathrm{QC}$ assays of newly generated MF wastes.

\subsection{NEVADA TEST SITE}

The NTS is a DOE interim CH-TRU waste storage site. The entire inventory of these wastes has now been assayed using the mobile PAN units. All the wastes stored at NTS contain low-fissile mass quantities (i.e., no drums are stored at NTS that contain more than $35 \mathrm{~g}$ of WG plutonium). The average plutonium loading per waste drum is $<5 \mathrm{~g}$ of WG plutonium. No significant quantities of HSG plutonium or other high-heat generation isotopes were found in these wastes. These wastes should then pose no heat source generation problems for TRUPACT II shipments.

The NDA technique comparison studies, ${ }^{13,35}$ as well as additional PAN assay verification measurements, provide confidence that these waste drums and crates have been assayed accurately. All data were acquired and analyzed by LANL personnel. The assay standards used during these measurements are the same ones used for the initial calibration performed at LANL for all current PAN units. In addition, a set of 15 plutonium waste standards drums (i.e., so-called "salted" drums containing known amounts of plutonium in actual waste matrices) were fabricated by an independent, non-DOE contractor to verify the mobile PAN unit assay system measurement during the NTS campaign. These 15 salted drums contain several isotopic ranges and quantities of 
plutonium (i.e., ranging between 1 and $16 \mathrm{~g}$ ). Results of these verification measurements have been published. ${ }^{23}$ Both pa isive and active mobile PAN unit measurements of these waste standards drums indicate waste drum plutonium assay average variances of $\pm 10 \%$.

\subsection{OAK RIDGE NATICNAL LABORATORY}

The ORNL drum-size PAN assay unit was the fiisi PAN unit to be placed and tested outsic - I.ANL. ${ }^{20,31}$ Upgraded twice, this original PAN system is configured in the PAN standard sccond-generation mode and includes systematic moderator and absorber matrix corrections and an IBM/PC control unit. The original passive and active neutron assay standards provided by $\mathrm{LANL}^{6}$ are used in the daily operational calibrations of the ORNL PAN unit. Opcrators are trained according to DOE guidelines. ${ }^{11}$

All of TRNL's CH-TRU waste drums are also assayed with an SGS unit. At present, this unit is undergoing an upgrade to enable performance of multienergy gamma-ray transmission corrected assays for each drum segment scanncd. This upgrade permits identification and quantities estimations by the SGS of any passive gamma rays emitted in sufficient quantities (i.e., above the lower limit of detection) that are present in a waste drum. ${ }^{35} \mathrm{~A}$ mixed ${ }^{152} \mathrm{Eu} /{ }^{154} \mathrm{Eu}$ oxide source that emits gamma rays spanning the 106 - :o 2000-keV range is used for the SGS transmision source. ORNL CH-TRU wastes generated in the Isotopes Area may contain rartionuclides such as ${ }^{243} \mathrm{Am},{ }^{239} \mathrm{~Np}$, and ${ }^{237} \mathrm{~Np}$. These radioisotopes are not commonly foun ${ }^{i}$ in ite same quantities in other DOE site CH-TRU wastes. The multienergy SGS system is usied to measure the quantities of these TRU isotopes as well as other more common TRU gamma-emitting radioisotopes such as ${ }^{241} \mathrm{Am}$. The PAN active assay measurements provide ORNL quantitative assay results for ${ }^{239} \mathrm{Pu},{ }^{233} \mathrm{U}$, and ${ }^{235} \mathrm{U}$, while the passive assay measurements provide quantitative assay results for ${ }^{240} \mathrm{Pu},{ }^{244} \mathrm{Cm}$, and ${ }^{252} \mathrm{Cf}$. Assay standards for all of the above-mentioned radioisotopes have been prepared at ORNL in accordance with accepted ASTM and ANSI procedures. ${ }^{210}$ These specific isotopic standards, as well as general SGS calibration sources (e.g., mixed ${ }^{152} \mathrm{Eu}_{-}{ }^{154} \mathrm{Eu}$ oxide source), are uscd to calibrate the SGS unit.

Because several isotopes produce both gamm? and neutron signatures, the SGS and PAN data are analyzed and compared to obtain 'he best assay values for each TRU isctope detected. At present, a data base (i.e., LOTUS 1-2-3 and dBASE III) is being prepared in which all gamma-ray and neutron measurement data will be compiled for each drum. This process is expected to expedite estimations of specific TRU isotope quantities for those drums containing multi-TRU-isotopic mixtures.

\subsection{WESTINGHOUSE HANFORD}

All CH-TRU waste drums generated at Hanford aie measured using two separate NDA systems. Wastes at Hanford are prescreened using a sensitive NaI unit set for $<10-\mathrm{g}$ and $>10$-g plutonium screening. Waste drums screened to the nominal $<10$-g stream are then sent to a PAN unit for final passive-active neutron assay. The active PAN neutron assay value is generally used as the final plutonium assay value of record. Waste drums screened to the $>10$-g plutonium siream are first sent to one of two SGS measurement stations: one used for wastes generated at the $\angle$ Plant and the other for the Purex Facility wastes. All drums identified to be in the $>10$-g plutonium stream are subsequently assayed with the PAN unit. Thus the waste drums that may be of most concern for TRUPACT II criticality safety and heat generation criteria have had three independent, quantitative 
NDA measurements of plutonium mass conducted: passive gamma, passive neutron, and active neutron.

All NDA measurement data are reviewed by a designated NDA expert or experts, and the appropriate plutonium mass to be used for the final assay of record is determined. All three waste assay values are maintained in a data base for future reference. If the three measurements cannot be reconciled, remedial action is taken. This may constitute a rcmeasurement of he waste drum if one of the assays appears suspect, but more often the remedial action taken is repackaging of the waste drum. Review of RTR records may reveal that one or more items contained in the drum may be causing assay anamolies (e.g., the presence of lead pigs may indicate the presence of radioisotope sources and, consequently, high neutron self-absorption). All SGS units and the PAN unit are operated according to the established standards and procedures for these NDA units discussed in detail in other sections.

\subsection{SAVANNAH RIVER SITE}

The SRS typically assays their CH-TRU wastes using two measurement techniques (three methods are used for one waste stream): one at the point of origin and another in the Experimental Transuranic Waste Assay Facility (ETWAF). The original assay measurements use the SGS (one waste stream is assayed using both SGS and PNCC). The ETWAF assay uses the PAN; this serves the function of verifying the original SGS and/or PNCC assays as well as identifying non-TRU [i.e., low-level waste (LLW)] drums. Upgrading of existing assay instrumentation and algorithms is in progress.

SRS currently classifies its wastes into five categories: (1) job control wastes (which are on the average $70 \%$ combustible and $30 \%$ miscellaneous metals), (2) high-efficiency particulate air filters, (3) resins, (4) sludges, and (5) miscellaneous. These are generated in four separate facilities:

1. FB Line generates primarily job control WG plutonium wastes together with smaller amounts of the other types. At present, job control wastes are assayed with three separate systems: SGS and PNCC at the point of origin and the PAN unit located at the ETWAF. The PAN unit serves to identify non-TRU wastes (LLW) that are then removed from the TRU stream. General agreement is found among the three methods for all but the fraction of FB Line waste drums in which the plutonium is compounded with fluorine. The high-tluorine-content plutonium waste drums cause the neutron assays generally to yield high-assay results because of $(\alpha, n)$ effects. An effort is now under way to institute $(\alpha, n)$ corrections to both sets of neutron data. At present, tag values are conservatively ascribed based on the highest value obtained.

2. HB Line processes job control HSG plutonium material (i.e., $80 \%{ }^{238} \mathrm{Pu}$ ). These wastes are assayed using an SGS unit at the point of origin and later at the ETWAF facility using a PAN unit. Non-TRU (LLW) drums are removed from the waste stream based on the PAN assay results.

3. Building 772-S is a laboratory operated in support of the FB Line operations. Waste generated at this facility is mostly job control type and is assayed with an SGS unit at the point of origin and with the PAN unit at the ETWAF.

4. Savannah River Laboratory generates miscellaneous wastes during research and development (K\&D) operations. Again, this waste is assayed with an SGS unit ai the point of origin and with the PAN unit at the ETWAF. 


\subsection{ROCKY FLATS PLANT}

CH-TRU waste streams generated at the RFP (defined by item description codes) are assayed with a large variety of NDA equipment (Table 7). The large number of counters is required because of (1) the large number of item description codes and (2) the many different locations of the waste-generating points.

Table 7. Rocky Flats Plant nondestructive assay

\begin{tabular}{|c|c|c|}
\hline $\begin{array}{l}\text { NDA } \\
\text { instrument }\end{array}$ & Type of instrument & Colloquial name \\
\hline 371SGSCSO4 & High-resolution gamma canscan-single pass & 371 CANSCAN IV \\
\hline 371SGSDC01 & $\begin{array}{l}\text { Low-/high-resolution gamma drum scan-double pass } \\
\text { (LLW/TRU sorting) }\end{array}$ & $\begin{array}{l}371 \text { Segmented Drum } \\
\text { Counter }\end{array}$ \\
\hline 371PADCI01 & Passive-active neutron drum counter (LIWW/TRU sorting) & (371) PADC \\
\hline 569SGSDC01 & $\begin{array}{l}\text { Low-/high-resolution gamma drum scan-double pass } \\
\text { (LLW/TRU sorting) }\end{array}$ & \\
\hline $5690 \mathrm{PCCI} 01$ & $\begin{array}{l}\text { High-resolution gamma plus passive neutron crate } \\
\text { counter }\end{array}$ & \\
\hline 569PACCI01 & Passive-active neutron crate counter (LLW/TRU sorting) & Crate Counter II (or PACC) \\
\hline 707SGSDC01 & IIigh-resolution gamma drum scan-single pass & $\begin{array}{l}707 \text { Segmented Drum } \\
\text { Counter }\end{array}$ \\
\hline 771SGSCS01 & High-resolution gamma canscan-single pass & CANSCAN I \\
\hline $771 \mathrm{SGSCSO2}$ & High-resolution gamma canscan-double pass & \\
\hline 771SGSCS03 & High-resolution gamma canscan-double pass & \\
\hline 77 iSGSCS04 & High-resolution gamma canscan-double pass & \\
\hline 771SGSDC01 & High-resolution gamma drum scan-single pass & $\begin{array}{l}771 \text { Segmented Drum } \\
\text { Counter }\end{array}$ \\
\hline 771SGSDC01 & $\begin{array}{l}\text { Low-resolution gamma drum counter plus neutron assay } \\
\text { capability }\end{array}$ & $\begin{array}{l}\text { South Drum Counter } \\
\text { (updated) }\end{array}$ \\
\hline 771HEPAI01 & $\begin{array}{l}\text { Low-resolution gamma IHEPA filter counter (LLW/TRU } \\
\text { sorting) }\end{array}$ & IIEPA Filter Counter \\
\hline 771PADCI01 & Passive-active neutron drum counter (LLW/TRU sorting) & $\begin{array}{l}\text { North Drum Counter } \\
\text { (updated) }\end{array}$ \\
\hline $776 \mathrm{SGSCS01}$ & High-resolution gamma canscan-single pass (out-of-line) & CANSCÁN II (out-line) \\
\hline $776 \mathrm{SGSCS} 02$ & High-resolution gamma canscan-single pass (in-line) & CANSCAN II (in-line) \\
\hline 776LOSAC01 & Low-resolution gamma drum scan (LL'W/TRU sorting) & $\begin{array}{l}\text { Low-Specific-Activity Counter } \\
\text { (LOSAC) }\end{array}$ \\
\hline
\end{tabular}

In Table 7, "low resolution" gamma scan utilizes thallium-activated sodium iodide detectors. "High resolution" describes germanium detector spectrometers. All gamma-ray counters are capable of segmented assay except LOSAC. The 771 SGSDC01 counter uses multiple, fixed position detectors with relatively wide collimation. All counters use automatic data processing and report the measurement results in hard copy output. Results are manually transferred to the plant's nuclear material control and safeguards data bases.

RFP NDA systems are calibrated using formal internal operating procedures based on standard guides and methods. ${ }^{1,5,10}$ Gamma assay systems are calibrated using either a synthetic standard or process material representative of each process stream ("small package"). Several SGS systems are sized for 4-L or smaller containers. The other SGS systems can accept larger waste packages, which are exclusively 55-gal drums at the RFP. The guidance of ANSI and ASTM methods is used to the extent possible. ${ }^{15,10}$ When practical, small packages from production streams are used to calibrate the appropriate 
SGS devices. The assay values assigned to these calibration packages are obtained by calorimetric methods discussed previously. ${ }^{9,36}$

Laboratory-prepared standards are used for calibrations when practical considerations preclude calibration with actual process materials. Preparation of one set of standards may be appropriate for several IDCs that satisfy the valid reference materials parameters (e.g., density, particle size, etc.) defined in the standard guides and methnds.

Experimental designs for calibration are the responsibility of the operational safeguards organization. Advice from statistic experts and R\&D personnel is sought when required. The R\&D personnel are used during new installations and initial calibrations before routine use is initiated. They may or may not consult on later recalibrations.

For 208-L drums and larger containers, calibrations with modular calibration materials constitute the only practical solution to initial measurement calibrations. No national standard method exists for using modular materials, but one ANSI standard has recognized the need in an appendix. ${ }^{10}$ Appendices to ANSI standards do not carry the full weight of recommended practice and are not officially part of ANSI standards.

Calibration protocols for PAN systems with modular standards were analogous to the above descriptions of gamma-ray calibrations. The PAN crate counter (569PACCI01) was systematically mapped with plutonium-bearing modules and a depleted uranium (D-38) bar containing $3 \mathrm{~g}$ of ${ }^{235} \mathrm{U}$. The ratio of ${ }^{235} \mathrm{U}$ response to ${ }^{239} \mathrm{Pu}$ response was measured with a relative uncertainty of about $2 \%$ of the ratio. This technique provided a means to use D-38 instead of plutonium for calibrations in any matrix of interest and, consequently, to correct for plutonium response.

The PAN drum counter (371PADCI01) was extensively studied at LANL and arrived with a "turn-key calibration." RFP has performed confirmatory measurements to test the calibrations. The counter 771PADCI01 calibration protocols are similar to the preceding descriptions but are not identical to the LANL design. 


\section{CONCLUSIONS}

All systems or methods discussed except PAN have established ASTM, ANSI, and/or NRC guidelines or methods that describe proper calibration procedures, proper equipment setup, etc. While PAN is a new technique and does not yet have a guideline or method developed, comparisons of PAN data with the more established assay methods (e.g., SGS) have demonstrated its reliability and accuracy. The assay methods employed by DOE have been shown to be reliable and accurate in determining fissile, radionuclide, alpha-curie content, and decay heat values of CH-TRU wastes. These parameters are therefore used to characterize the packaged waste for use in certification programs such as that used in the shipment of CH-TRU wastes to the WIPP. 


\section{REFERENCES}

1. "American National Standard Guide to Calibrating Nondestructive Assay Systems," ANSI N15.20-1975, American Natl. Standards Institute, New York.

2. "Nondestructive Assay of Special Nuclear Material Contained in Scrap and Waste," Regulation Guide 5.22, rev. 1, U.S. Nuclear Regulatory Commission, April 1984.

3. "Standard Terminology Relating to Nuclear Materials," ASTM C 859-87, American Society for Testing and Materials, Philadelphia.

4. "Standard Test Method for Nondestructive Assay of Special Nuclear Material in Low Density Scrap and Waste by Segmented Passive Gamma-Ray Scanning," ASTM C 853, American Society for Testing and Materials, Philadelphia. This draft standard has been referenced with permission from ASTM Subcommittee C-26.10.

5. "Standard Test Methods for Nondestructive Assay of Special Nuclear Materials Contained in Scrap and Waste," ASTM C 853-82, American Society for Testing and Materials, Philadelphia.

6. J. T. Caldwell et al., The Los Alamos Second-Generation System for Passive and Active Neutron Assays of Drum-Size Containers, LA-10774-MS, Los Alamos Natl. Lab., Los Alamos. N.M., September 1986.

7. J. T. Caldwell et al., System Evaluation Including Assay Algorithm, Matrix Corrections, and Operational Performance of the Los Alamos Passive/Active Neutron Assay Systems, N2-87-222WP, Los Alamos Natl. Lab., Los Alamos, N.M., 1989.

8. R. B. Perry, R. W. Brandenburg, and N. S. Beyer, "The Effect of Induced Fission on Plutonium Assay with a Neutron Coincidence Well Counter," Trans. Am. Nucl. Soc. 15, 674 (1972).

9. "American National Standard Calibration Techniques for the Calorimetric Assay of Plutonium Bearing Solids Applied to Nuclear Materials Control," ANSI-N15.22-1975, American National Standards Institute, New York (rev. to 1985).

10. "Guide to Preparing Calibration Material for Nondestructive Assay Systems that Count Passive Gamma Rays," ANSI N15.35, American Natl. Standards Institute, New York.

11. "Safety of Nuclear Facilities," DOE Order 5480.5, U.S. DOE, Sept. 23, 1986.

12. John G. Feissner and Merril W. Hume, Comparison of Destructive and Nondestructive Assay of Heterogeneous Salt Residues, RFP-3876, Rocky Flats Plant, Mar. 29, 1986.

13. F. J. Schultz, "Survey of DOE NDA Practices for CH-TRU Waste Certification-lllustrated with a Greater than 10,000-Drum NDA Data Base," in DOE Model Conference Proceedings, October 3-7, 1988.

14. "Methods for Chemical, Mass Spectrometric, and Spectrochemical Analysis of Nuclear-Grade Uranium Dioxide Powders and Pellets," ASTM C696-80, American Society for Testing and Materials, Philadelphia.

15. "Methods for Chemical, Mass Spectrometric, and Spectrochemical Analysis of Nuclear-Grade

Plutonium Dioxide Powders and Pellets," ASTM C 697-86, American Society for Testing and Materials, Philadelphia.

16. "Methods for Chemical, Mass Spectrometric, Spectrochemical, Nuclear, and Radiochemical Analysis for Nuclear-Grade Plutonium Nitrate Solutions," ASTM C 759-79, American Society for Testing and Materials;, Philadelphia.

17. J. E. Swansen, P. R. Collinsworth, and M. S. Krick, Shift-Register Coincidence Electronics Systern for Thermal Neutron Counters, LA-8319-MS, Los Alamos Natl. Lab., Los Alamos, N.M., April 1980.

18. J. E. Swansen, Dead-time Reduction in Thermal Neutron Coincidence Counter, LA-9936-MS, Los Alamos Natl. Lab., Los Alamos, N.M., March 1984.

19. M. E. Anderson and J. F. Lemming, Selected Measurement Data for Plutonitum and Uranium, MLM3009 (ISPO-157), November 1982, Table 5, p. 33.

20. F. J. Schultz et al., First-Year Evaluation of a Nondestructive Assay System for the Examination of ORNL TRU Waste, ORNL-6007, Martin Marietta Energy Systems, Oak Ridge Natl. Lab., April 1984.

21. T. H. Kuckertz et al., "Making Transuranics Assay Measurements Using Modern Controllers," pp. 389-93 in Proceedings of the 9th ESARDA Symposium on Safeguards and Nuclear Material Management, London, United Kingdom, May 1987.

22. J. T. Caldwell, J. M. Bieri, and A. P. Colarusso, The Los Alamos Second-Generation Passive-Active Neutron Assay System-FY 86 Operations Record and System Evaluation, LA-Q2TN-86-106, Los Alamos Natl. Lab., Los Alamos, N.M., September 1986.

23. A. P. Colarusso et al., "Mobile Nondestructive Assay System," in Proceedings of the 28th Annual INMM Meeting, New'port Beach, Culifornia, July 12-15, 1987. 
24. K. L. Coop, J. T. Caldwell, and C. A. Goulding, "Assay of Fissile Materials Using a Combined Thermal/Epithermal Neutron Interrogation Technique," in Third International Conference on Facility Operations-Safeguards Interface, San Diego, California, November 29-December 4, 1987.

25. "Nuclear Criticality Control of Special Actinide Elements," ANSI/ANS-8.15-1981, American Natl. Standards Institute, New York.

26. TRU Waste Acceptance Criteria for the Waste Isolation Pilot Plant, WIPP-DOE-069, rev. 2, Westinghouse Elec. Corp., September 1985.

27. Data Package Format for Certified Transuranic Waste for the Waste Isolation Pilot Plant, WIPP-DOE157, rev. 2, Westinghouse Elec. Corp., January 1989.

28. C. E. Moss and J. T. Caldwell, Assay of TRU Wastes Containing (alpha, n) Sources, LA UR 86-2220, Los Alamos Natl. Lab., Los Alamos, N.M., June 22, 1986.

29. Chart of the Nuclides, Knolls Atomic Power Laboratory.

30. David C. Kocher, Radioactive Decay Data Tables, DOE/TIC-11026, U.S. DOE, 1981.

31. F. J. Schultz et al., Neutron and Gamma-Ray Nondestructive Examination of Contact-IIandled Transuranic Waste at the ORNL TRU Waste Drum Assay Facility, ORNL-6103, Martin Marietta Energy Systems, Oak Ridge Natl. Lab., March 1985.

32. San Horton, "Neutron Imaging," Ph.D. thesis, U.S. Army, 1988.

33. Quality Assurance Plan, WIPP-DOE 120, Westinghouse Elec. Corp.

34. J. T. Caldwell, "Second Generation Passive Active Neutron Assay System," pp. 389-93 in Proceedings of the 9th ESARDA Symposium on Safeguards and Nuclear Material Management, London, United Kingdom, May 12-14, 1987.

35. D. A. Close et al., "Multi-Isotopic Gamma Ray System for Alpha Contaminated Wastes," in Proceedings of the 24th Annual INMM Meeting, Vail, Colorado, July 1983.

36. "Standard Test Method for Determination of Plutonium Isotopic Composition by Gamma-Ray Spectrometry," ASTM C 1030-84, American Society for Testing and Materials, Philadelphia. 


\section{Internal Distribution}

1. H. L. Adair

2. J. P. Adams

3. R. D. Bailey

4. V. M. Baylor

5. J. B. Berry

6. J. Bolinsky

7. R. W. Brandenburg

8. B. A. Caylor

9. J. A. Chapman

10. P. G. Cleveland

11. D. E. Coffey

12. J. N. Coolcy

13. K. G. Edgemon

14. C. E. Frye

15. R. C. Hagenauer

16. D. F. Hall

17. F. K. Heacker

18. D. C. Hensley

19. S. C. Howard

20. L. S. Jones

21. G. E. Kamp

22. A. P. Malinauskas
23. C. P. Manrod

24. L. J. Mezga

25. B. C. McClelland

26. S. A. McKenney

27. L. E. McNeese

28. J. T. Mihalczo

29. J. C. Patterson

30. T. H. Row

31. T. F. Scanlan

32. J. A. Setaro

33-42. F. J. Schultz

43. M. W. Tull

44. D. W. Tumer

45. J. E. Van Cleve, Jr.

46. J. L Westbrook

47. Central Research Library

48-49. ORNL Laboratory Records

50. ORNL Laboratory Records-RC

51. Y-12 Sitc Technical Library

52. ORGDP Library

53. Patent Section

\section{External Distribution}

54. Donna Aldrich, EG\&G Idaho, Inc., Idaho National Engineering Laboratory, P.O. Box 1625, Idaho Falls, ID 83415-2209

55. Roger Allman, Nuclear Fuel Services, 1205 Banner Hill Road, Erwin, TN 37650

56. Cecelia Amaro, EG\&G Idaho, Inc., P.O. Box 1625, Idaho Falls, ID 83415

57. B. C. Anderson, Westinghouse Electric Corporation, TRU Waste and Integration, 101 W. Green St., Carlsbad, NM 88221

58. Terry Arrington, EG\&G Idaho, Inc., P.O. Box 1625, Idaho Falls, ID 83415

59. Sharleen Asbury, Westinghouse Electric Corporation, TRU Waste and Integration, 101 W. Green St., Carlsbad, NM 88221

60. Linda Askem, Westinghouse Electric Corporation, TRU Waste and Integration, 101 W. Green St., Carlsbad, NM 88221

61. Hank Batchelder, Westinghouse Electric Corporation, TRU Waste and Integration, 101 W. Green St., Carlsbad, NM 88221 
62. Fred Bauer, U.S. Department of Energy, Idaho Operations Office, 785 DOE Place, MS 1119, Idaho Falls, ID 83402

63. Greg Becker, EG\&G Idaho, Inc., Idaho National Engineering Laboratory, MS-7113, P.O. Box 1625, Idaho Falls, ID 83415-2209

64. J. Mike Bieri, 278 DP Road, Los Alamos, NM 87544

65. Dennis Bingham, EG\&G Idaho, Inc., P.O. Box 1625, Idaho, Falls, ID 83415

66. J. Blakeslee, EG\&G, Rocky Flats, Inc., NID, Building 881, Golden, CO 80402-0464

67. Michacl Brennan, WSRC, P.O. Box 616-707H, Aiken, SC 29802

68. Rich Brey, EG\&G Idaho, Inc., P.O. Box 1625, MS 1406, Idaho Falls, ID 83415

69. Anne Brown, EG\&G Idaho, Inc., P.O. Box 1625, Idaho Falls, ID 83415

70. Susan Burris, Idaho State University, P.O. Box 1625, Idaho Falls, ID 83415

71-80. John T. Caldwell, Pajarito Scientific Corporation, 322 Kimberly, Los Alamos, NM 87544

81. David Camp, Lawrence Livermore National Laboratory, P.O. Box 808, Livermore, CA 94550

82. Mike Caviness, Westinghouse Electric Corporation, TRU Waste and Integration, 101 W. Green St., Carlsbad, NM 88221

83. Tom Clements, EG\&G Idaho, Inc., P.O. Box 1625, Idaho Falls, ID 83415

84. Don Close, Los Alamos National Laboratory, P.O. Box 1663, Los Alamos, NM 87545

85. Jeff Cook, EG\&G Idaho, Inc., Idaho National Engineering Laboratory, P.O. Box 1625, Idaho Falls, ID 83415-2209

86. Ken Coop, Los Alamos National Laboratory, P.O. Box 1663, N-2, MS J562, Los Alamos, NM 87545

87. Tom Curry, EG\&G Idaho, Inc., P.O. Box 1625, Idaho Falls, ID 83415

88. Hal Davis, U.S. Department of Energy, Waste Isolation Pilot Plant, Carlsbad, NM 88221

89. Ralph Ditch, Argonne National Laboratory-East, 9700 S. Cass Avenue, Bldg. 306, Argonne, IL 60439

90. Kevin Donovan, Westinghouse Electric Corporation, TRU Waste and Integration, 101 W. Green St., Carlsbad, NM 88221

91. Paul Drez, IT Corporation, Suite 700, 5301 Central Ave., NE, Albuquerque, NM

92. Allen E. Dross, Los Alamos National Laboratory, P.O. Box 1663, HSE-7, MS-J594, Los Alamos, NM 87545

93. Martin Edelson, Iowa State University, Ames Laboratory, Ames, IA 50011

94. Robert Estep, Los Alamos National Laboratory, P.O. Box 1663, MS J562, Los Alamos, NM 87545

95. Paul Fehlau, Los Alamos National Laboratory, P.O. Box 1663, Los Alamos, NM 87545

96. Clyde Frank, OTD, U.S. Department of Energy, Washington, DC 20545

97. Lou Garvey, Westinghouse Electric Corporation, TRU Waste and Integration, 101 W. Green St., Carlsbad, NM 88221

98. David George, Chem. Nuclear Geotech., P.O. Box 14000, Grand Junction, CO 81502

99. Ann Gibbs, Westinghouse Savannah River Co., P.O. Box 616, Building 707-C, Aiken, SC 29802

100. Bill Giles, Westinghouse Hanford Corporation, P.O. Box 1970, A1-10, Richland, WA 99352

101. Bruce Gillespie, Canberra Ind., One State St., Meriden, CT 06450 
102. Phil Gregory, Westinghouse Electric Corporation, TRU Waste and Integration, 101 W. Green St., Carlsbad, NM 88221

103. Jeffrey Griffin, Westinghouse Savannah Co., 469 Greenwich Dr., Aiken, SC 29803

104. Bill Haas, Iowa State University, Ames Laboratory, Ames, IA 50011

105. Fran Haas, EG\&G, Rocky Flats, Inc., NID, Bldg. 881, Golden, CO 80402-0464

106. Robert Hamm, AccSys Technology, Inc., 1177-A Quarry Lanc, Pleasanton, CA 94566

107. Ron A. Harlan, EG\&G, Rocky Flats, Inc., Nuclear Instrumentation Development, MS-881, P.O. Box 464, Golden, CO 80402-0464

108. Frank Harmon, Idaho State University, Campus Box 8106, Pocatello, ID 83209

109. Diane Hartley, EG\&G Idaho, Inc., Idaho National Engineering Laboratory, P.O. Box 1625, Idaho Falls, ID 83415-4203

110. San Horton, Nuclear Measurement Technologies, 8104 Otero Avenuc, NE, Albuquerque, NM 87109

111. Q. D. Howard, EG\&G Idaho, Inc., $503 \mathrm{~N} 400 \mathrm{~W}$, Blackfoot, ID 83221

112. Arlen Hunt, U.S. Department of Energy, Waste Isolation Pilot Plant, Carlsbad, NM 88221

113. J. Paul Hurley, Special Technologies Laboratory, Santa Barbara, CA 93111

114. Jack Johnson, Westinghouse Electric Corporation, TRU Waste and Integration, 101 W. Green St., Carlsbad, NM 88221

115. Larry Johnson, EG\&G Idaho, Inc., 367 W 170 N, Blackfoot, ID 83221

116. J. R. Kanvinen, EG\&G Idaho, Inc., P.O. Box 1625, Idaho Falls, ID 83415

117. Edward Kelley, Idaho State University, Campus Box 8106, Pocatcllo, ID 83209

118. Tom Kerlin, The University of Tennessee, Nuclear Enginecring Department, Knoxville, TN 37902

119. Robert E. Kerns, Westinghouse Hanford Corporation, P.O. Box 1970, T6-16, 2355 Stevens, Richland, WA 99352

120. T. B. Klingler, EG\&G Idaho, Inc., P.O. Box 1625, Idaho Falls, ID 83415

121. Zachary M. Koenig, L-233, Lawrence Livermore National Laboratory, P.O. Box 808, Livermore, CA 94550

122. K. Pat Lange, EG\&G Idaho, Inc., P.O. Box 1625, MS 3970, Idaho Falls, ID 83415

123. W. N. Lingle, U.S. Department of Energy, Oak Ridge Field Office, P.O. Box 2001, Oak Ridge, TN 37831

124. Richard Lipinski, Westinghouse Hanford Corporation, P.O. Box 1970, A1-10, Richland, WA 99352

125. Joe Lippis, U.S. Department of Energy, Waste Isolation Pilot Plant, Carlsbad, NM 88221

126. Sheila Lott, Westinghouse Electric Corporation, TRU Waste and Integration, $101 \mathrm{~W}$. Green St., Carlsbad, NM 88221

127. Jon Lott, Westinghouse Electric Corporation, TRU Waste and Integration, $101 \mathrm{~W}$. Green St., Carlsbad, NM 88221

128. Jill Lyttle, U.S. Department of Energy, Washington, DC 20545

129. Harry E. Martz, Jr., Nondestructive Evaluation Section, Lawrence Livermore National Laboratory, P.O. Box 808, L-333, Livermore, CA 94550

130. Charles D. Massey, Sandia National Laboratories, P.O. Box 5800, Division 3222, Albuquerque, NM 87185

131. John Mathur, U.S. Department of Energy, Washington, DC 20545

132. Mike McFadden, U.S. Department of Energy, Waste Isolation Pilot Plant, Carlsbad, NM 88221 
133. Jerry N. McKamy, Rockwell International Corporation, Rocky Flats Plant, P.O. Box 464, Building 750, Golden, CO 80402-0464

134. Gary McLaughlin, EG\&G Idaho, Inc., 352 Kurtwood Place, Pocatello, ID 83204

135. Jean Meadows, EG\&G Idaho, Inc., P.O. Box 1625, Idaho Falls, ID 83415

136. Chuck Mikesell, EG\&G Idaho, Inc., Idaho National Engineering Laboratory, P.O. Box 1625, Idaho Falls, ID 83415

137. Ken Mikus, WIPP Project, Westinghouse Electric Corporation, P.O. Box 2078, Carlsbad, NM 88221-2078

138. Larry F. Miller, The University of Tennessee, Nuclear Enginecring Department, Knoxville, TN 37902

139. C. Dennis Morissette, WIPP Project, Westinghouse Electric Corporation, P.O. Box 2078, Carlsbad, NM 88221-2078

14C. Robert Mullin, EG\&G Idaho, Inc., 68611 th St., Idaho Falls, ID 83404

141. Tim E. Myrick, Science Applications International Corporation, P.O. Box 2501, Oak Ridge, TN 37830

142. Nancy Jo Nicholas, Los Alamos National laboratory, LANL Group N-2, MS J562, Los Alamos, NM 87545

143. E. B. Nieschmidt, EG\&G Idaho, Inc., P.O. Box 1625, Idaho Falls, ID 83415

144. Daniel Osetek, 6501 Americas Parkway NE, Albuquerque, NM 87110

145. Larry Patrick, Westinghouse Electric Corporation, TRU Waste and Integration, 101 W. Green St., Carlsbad, NM 88221

146. Robert Pink, EG\&G Idaho, Inc., 202 Hawthome Ave., Pocatello, ID 83204

147. Don Pound, MS-4203, EG\&G Idaho, Inc., Idaho National Engineering Laboratory, Idaho, Falls, ID 83415

148. Wes Pugmire, Nevada Test Site, P.O. Box 98521, MS-628, Las Vegas, NV 89193-8521

149. Mike Purcell, Westinghouse Hanford Corporation, 2355 Stevens, P.O. Box 1970, T6-16, Richland, WA 99352

150. William Quapp, EG\&G Idaho, Inc., P.O. Box 1625, Idaho Falls, ID 83415

151. David Quisenberry, Nuclear Fuel Serv., Inc., 1205 Banner Hill Rd., Erwin, TN 37630

152. Brian Raivo, EG\&G Idaho, Inc., P.O. Box 1625, MS 3416, Idaho Falls, ID 83415

153. Bruce Reich, Los Alamos National Laboratory, P.O. Box 1663, Los Alamos, NM 87545

154. Dan Remington, EG\&G Rocky Flats, Inc., Safeguards Measurements, Building 750 , P.O. Box 464, Golden, CO 80401

155. Dwayne Rencken, Scientific Ecology Group, P.O. Box 253D, 1560 Bear Creek Road, Oak Ridge, TN 37830

156. Jeff Riedesel, EG\&G Idaho, Inc., P.O. Box 1625, MS 3950, Idaho Falls, ID 83415

157. Don Roberts, Westinghouse Electric Corporation, TRU Waste and Integration, 101 W. Green St., Carlsbad, NM 88221

158. Tim Roney, EG\&G Idaho, Inc., P.O. Box 1625, MS 2209, Idaho Falls, ID 83415

159. Brendan Ryan, U.S. Department of Energy, 812 Whittier, Idaho Falls, ID 83401

160. Patti Sallani, U.S. Department of Energy, Waste Isolation Pilot Plant, Carlsbad, NM 88221

161. Walter Lynard Sansbury, 204 S. 5th Ave., Pocatello, ID 83201

162. Scott Serrano, EG\&G Idaho, Inc., 4870 Mohawk, Pocatello, ID 83204

163. Joe Shappell, Savannah River Plant, Building 703-H, Aiken, SC 29808

164. Farok Sharif, Westinghouse Electric Corporation, TRU Waste and Integration, 101 W. Green St., Carlsbad, NM 88221 
165. Camille Shocmake, Westinghouse Electric Corporation, TRU Waste and Integration, 101 W. Green St., Carlsbad, NM 88221

166. David Shropshire, EG\&G Idaho, Inc., P.O. Box 1625, Idaho Falls, ID 83415

167. Raymond Sigg, Westinghouse Savannah Co., 773A, B140, Aiken, SC 29802

168. Jim Smith, Westinghouse Electric Corporation, TRU Waste and Integration, $101 \mathrm{~W}$. Green St., Carlsbad, NM 88221

169. Mark Smith, Science Applications International Corporation, P.O. Box 2501, Oak Ridge, TN 37830

170. J. Richard Smith, EG\&G Idaho, Inc., Idaho National Engineering Laboratory, Physics and Mathematics, Idaho Falls, ID 83415

171. Bob Spooner, U.S. Department of Energy, Waste Isolation Pilot Plant, Carlsbad, NM 88221

172. James K. Sprinkle, Jr., Los Alamos National Laboratory, N-1, MS-E540, P.O. Box 1663, Los Alamos, NM 87545

173. Dan Standiford, Westinghouse Electric Corporation, TRU Waste and Integration, 101 W. Green St., Carlsbad, NM 88221

174. Don Staples, EG\&G Idaho, Inc., 270 Alpine Drive, Idaho Falls, ID 83402

175. Tom Stroud, Westinghouse Electric Corporation, TRU Waste and Integration, 101 W. Green St., Carlsbad, NM 88221

176. T. P. Stuart, EG\&G Energy, Las Vegas, NV 89108

177. Susan Stull, Lawrence Livermore National Laboratory, P.O. Box 808, L-205, 700 E Avenue, Livermore, CA 94550

178. Vishnu Subrahmanyam, Westinghouse Hanford Corporation, P.O. Box 1979, T6-31, Richland, WA 99352

179. J. Andrew Tompkins, Science Applications International Corporation, 2109 Air Park SE, Albuquerque, NM 87106

180. David Tow, EG\&G Idaho, Inc., P.O. Box 1625, Idaho Falls, ID 83415

181. Lenard E. Trimmer, MS-J594 HSE-7, Los Alamos National Laboratory, P.O. Box 1663, Los Alamos, NM 87545

182. Stanley Vegors, Idaho State University, Campus Box 8106, Pocatello, ID 83209

183. Jack Vigil, Los Alamos National Laboratory, P.O. Box 163, MS-J594, Los Alamos, NM 87545

184. George Vourvopoulos, Department of Physics and Astronomy, Westem Kentucky University, Bowling Green, KY 42102

185. Tom Ward, Westinghouse Electric Corporation, TRU Waste and Integration, $101 \mathrm{~W}$. Green St., Carlsbad, NM 88221

186. Larry Watson, EG\&G Idaho, Inc., P.O. Box 1625, Idaho Falls, ID 83415

187. John H. Weinkin, Sandia National Laboratories, P.O. Box 5800, DW 2364, Albuquerque, NM 87185

188. Dale Wells, EG\&G Idaho, Inc., P.O. Box 1625, Idaho Falls, ID 83415

189. Mike West, Nuclear Fuel Services, 205 Banner Hill Road, Erwin, TN 37650

190. Steven Winston, AWC, Inc., 900 Grier Dr. \#B, Las Vegas, NV 89119

191-722. Given distribution as shown in DOE/OSTI-4500/R75 under UC-721 Defense Waste Management Category (25 copies-NTIS) 

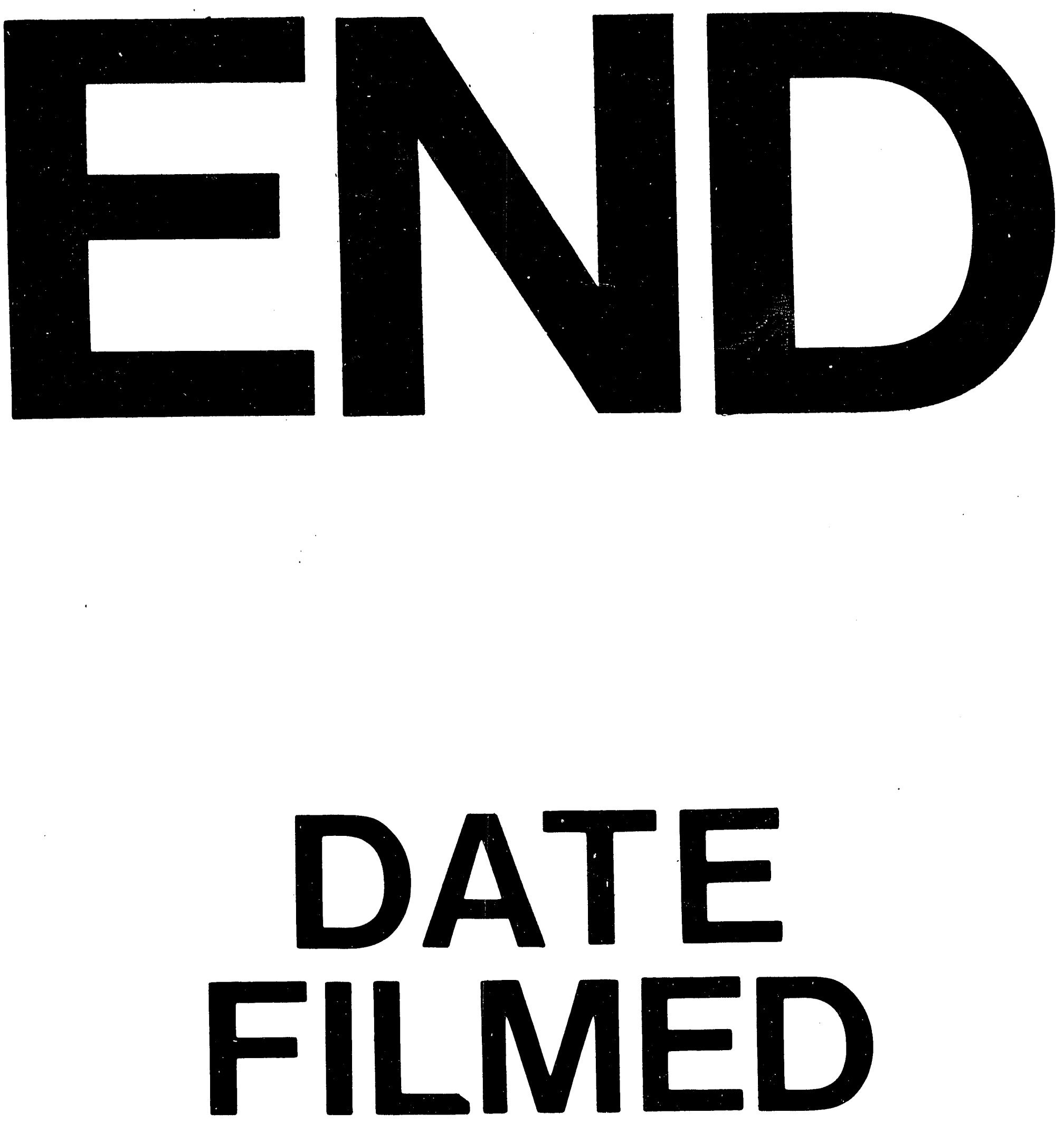

I

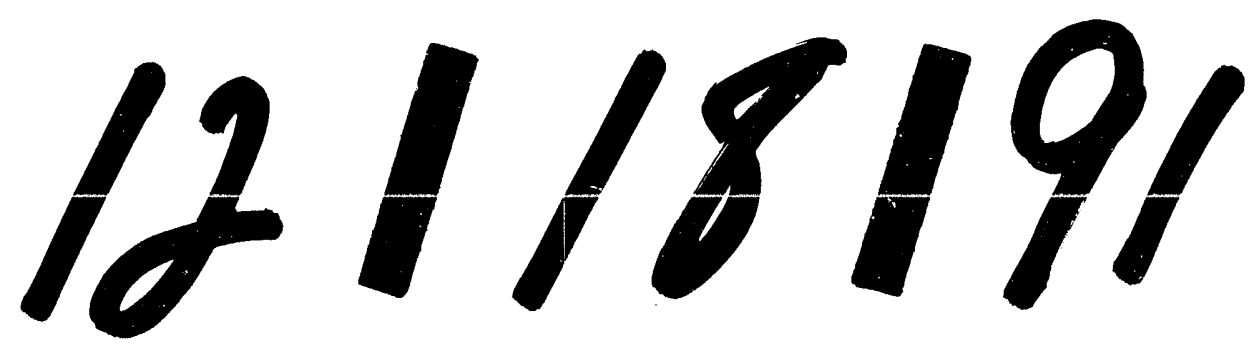

I" 
